\title{
Relations between Intracellular lons and Energy Metabolism: A Study with Monensin in Synaptosomes, Neurons, and C6 Glioma Cells
}

\author{
Maria Erecińska, ${ }^{1}$ Fiorenzo Dagani, ${ }^{2}$ David Nelson, ${ }^{1}$ Judith Deas, ${ }^{3}$ and lan A. Silver ${ }^{3}$ \\ 'Department of Pharmacology, University of Pennsylvania, Philadelphia, Pennsylvania 19104, 2 Istituto di Farmacologia, \\ Facoltà di Scienze, Università di Pavia, 27100 Pavia, Italy, and 'Department of Pathology, University of Bristol, Bristol, B58 \\ 1TD United Kingdom
}

Treatment of rat brain synaptosomes with $10 \mu \mathrm{M}$ monensin stimulated activity of the $\mathrm{Na} / \mathrm{K}$ pump, which enhanced oxygen consumption and lactate production. Glycolytic flux was also increased independently of the pump activation by a fall in $\left[\mathrm{H}^{+}\right]_{i}$. Under such conditions, glycolysis provided $26 \%$ of ATP for the ouabain-sensitive ATPase, a value substantially greater than the $4 \%$ obtained in veratridine-treated preparations (Erecińska and Dagani, 1990). In C6 glioma cells, a glia-derived line endowed with high rates of aerobic lactate synthesis, the cytosolic and mitochondrial ATP generation contributed $50 \%$ each for the support of the pump in the presence of $10 \mu \mathrm{M}$ monensin. The fraction of energy utilized by the pump was greater in synaptosomes than in C6 cells. Enhancement of ion movements was accompanied by changes in the levels of high-energy phosphate compounds. Measurements with ion-sensitive microelectrodes in $\mathbf{C 6}$ cells and cultured neurons showed that monensin caused an increase in $\mathrm{pH}_{1}$ by $0.4-0.5$ unit and a parallel rise in $\left[\mathrm{Na}^{+}\right]$. The increases in $\left[\mathrm{Na}^{+}\right]$, were about twofold in both types of cells, but the absolute values attained were much higher in neurons (40-50 mM) than in C6 cells (10-12 $\mathrm{mm}$ ). Membrane potentials transiently declined by less than 10 $\mathrm{mV}$ and returned to their original values after $\mathbf{2 0}$ min of treatment. Rises in $\left[\mathrm{Ca}^{2+}\right]$, were small in neurons as well as in C6 cells. These changes could be explained by the known mechanism and/or consequences of monensin action. In contrast, in synaptosomes monensin caused an internal alkalinization of $0.1-0.15 \mathrm{pH}$ unit, a large depolarization of the plasma membrane, and massive leakage of potassium into the external medium. The decrease in plasma membrane potential was accompanied by an increase in $\left[\mathrm{Ca}^{2+}\right]_{1}$ and release of the neurotransmitter amino acids GABA, aspartate, and glutamate. The depolarization and loss of $\mathrm{K}^{+}$were unaffected by calcium withdrawal, replacement of chloride with gluconate, and addition of $1 \mathrm{~mm}$ 4-acetamido-4'-isothiocyanostilebene-2,2'-disulfonic acid (SITS), but was markedly attenuated by elimination of $\mathrm{Na}^{+}$. It is proposed that in synaptosomes monensin and/or the consequences

Received Oct. 1, 1990; revised Feb. 28, 1991; accepted Mar. 6, 1991

This work was supported by NIH Grant NS 28329

Correspondence should be addressed to Dr. Maria Erecińska, Department of Pharmacology, University of Pennsylvania, School of Medicine, Philadelphia, PA 19104-6084.

Copyright (c) 1991 Society for Neuroscience $0270-6474 / 91 / 112410-08 \$ 03.00 / 0$ of its action open a nonspecific cation channel that allows $\mathrm{Na}^{+}$entry and $\mathrm{K}+$ exit, with a consequent decrease in membrane potential.

The major portion of the energy synthesized by the mammalian CNS is used for maintenance of proper ionic balances (Erecińska and Silver, 1989). In hypoxia and ischemia, conditions that limit $\mathrm{O}_{2}$ delivery, the ion gradients collapse rapidly (Hansen, 1985), and if it is not restored within minutes, permanent cell damage may ensue. This extreme sensitivity of brain to lack of oxygen implies that mitochondrial oxidative phosphorylation is the main source of energy for the reactions that maintain ions in a nonequilibrium state. Consistent with this supposition, we have shown previously (Erecińska and Dagani, 1990) that, in isolated nerve endings (synaptosomes) under both resting and veratridine-stimulated conditions, the ouabain-sensitive $\mathrm{Na} / \mathrm{K}$ ATPase, the key enzyme responsible for maintaining ion gradients in mammalian cells, is fueled almost exclusively by ATP provided by the mitochondrial respiratory chain. Because glycolysis is the preferred source of energy for $\mathrm{Na} / \mathrm{K}$ ATPase in several other systems (Paul et al., 1979; Lynch and Paul, 1983; Paul, 1983; Lynch and Balaban, 1987; Mertens et al., 1990), we felt it was important to understand the mechanisms that determine which of the energy-producing pathways assumes the task of providing ATP for this enzyme.

In approaching the problem, we have used monensin, an antibiotic that mediates electroneutral exchange of external $\mathrm{Na}^{+}$ for internal $\mathrm{H}^{+}$(Pressman, 1976; Pressman and Fahim, 1982). The consequence of its action on cells is a rise in $\left[\mathrm{Na}^{+}\right]_{i}$ and a fall in $\left[\mathrm{H}^{+}\right]_{i}$. The former stimulates the activity of the $\mathrm{Na} / \mathrm{K}$ pump and consequently increases cellular energy utilization. The latter activates glycolysis through its action on phosphofructokinase (Trivedi and Danforth, 1966); thus, increase in energy demand occurs simultaneously with an independently enhanced rate of ATP generation in the cytoplasm.

The effects of monensin were investigated in three systems: neurons, their endings, and C6 glioma cells. The nerve-ending particles, synaptosomes, retain a number of properties of nerve cells and provide a useful in vitro model for the presynaptic part of neuronal synapses. They are well suited for studies on relations between ion movements and energy utilization because their plasma membranes contain a large number of ionic channels. C6 glioma cells exhibit several characteristics of astrocytes and have been used extensively as a model for ccrcbral glia (Erecińska and Silver, 1986, and references therein). An interesting property of these cells is that, unlike synaptosomes, they 
produce lactate avidly under aerobic conditions (Erecińska and Silver, 1987) and hence, even in the absence of monensin, represent a system that derives a substantial proportion of its ATP synthesis from glycolysis. Because monensin affects transmembrane distribution of sodium and protons, we have measured, whenever feasible, their internal concentrations together with those of calcium and potassium and membrane potentials. Such information, on the one hand, allows correlations between alterations in the levels of intracellular ions and metabolic responses of the cell; on the other, it provides insight into events that occur upon stimulation of the $\mathrm{Na}^{+} / \mathrm{H}^{+}$exchanger, a protein present in membranes of both synaptosomes (Jean et al., 1985) and C6 cells (Benos and Sapirstein, 1983; Jean et al., 1986) and whose action is mimicked by monensin.

\section{Materials and Methods}

\section{Experiments on synaptosomes}

Male Sprague-Dawley rats $(220-250 \mathrm{gm})$ were used throughout the study. Synaptosomes were isolated from the forebrains and midbrains as described by Booth and Clark (1978). In most experiments, the synaptosomal pellet was washed and suspended in a modified Krebs-Henseleit buffer (130 mM NaCl, $5 \mathrm{~mm} \mathrm{KCl,} 1 \mathrm{~mm} \mathrm{NaH}_{2} \mathrm{PO}_{4}, 1.3 \mathrm{~mm} \mathrm{MgSO}_{4}$, $5 \mathrm{~mm} \mathrm{NaHCO}_{3}$ ) containing $10 \mathrm{~mm} \mathrm{Na}-\mathrm{N}$-2-hydroxyethylpiperazine- $\mathrm{N}$ ethane sulfonic acid (HEPES), pH 7.4. Synaptosomes stored on ice maintained their metabolic competence for at least $3 \mathrm{hr}$, and all experiments were performed within that period.

Preincubation conditions. Synaptosomes were preincubated for 10 min at $30^{\circ} \mathrm{C}$ in a shaking water bath. In most experiments, the suspension was supplemented with $10 \mathrm{~mm}$ glucose and $1.27 \mathrm{mM} \mathrm{CaCl}_{2}$. [Glucose] was decreased to $0.5 \mathrm{~mm}$ when 2-deoxyglucose uptake was evaluated. In experiments where $\mathrm{Na}^{+}$or $\mathrm{Ca}^{2+}$ was omitted, equimolar choline chloride was substituted for $\mathrm{NaCl}$, or $10 \mathrm{mM} \mathrm{MgCl}_{2}$ was added instead of $\mathrm{CaCl}_{2}$, as specified in the text. In experiments where chloride was removed, sodium and potassium gluconate were added to the medium.

Transplasma membrane ${ }^{86} \mathrm{Rb}$ gradients. Rates of ${ }^{86} \mathrm{Rb}$ uptake and its distribution across the plasma membrane were measured according to the method of Scott and Nicholls (1980). After preincubation, aliquots of synaptosomal suspensions were transferred to 25-ml Erlenmeyer flasks containing $50 \mu \mathrm{M}{ }^{86} \mathrm{RbCl}\left(0.1-0.3 \mu \mathrm{Ci} / \mathrm{ml} ;{ }^{86} \mathrm{Rb}, 20 \mathrm{Ci} / \mathrm{gm}\right.$, New England Nuclear, Boston, MA) and various test compounds, as required by the experimental protocol. Samples $(350 \mu \mathrm{l})$ were withdrawn after $0.5,1$, 3,5 , and $30 \mathrm{~min}$ of incubation and centrifuged $\left(1 \mathrm{~min}, 13,000 \times \mathrm{g}_{\mathrm{g}}\right)$ through a layer of silicone oil (1.03 specific gravity; General Electric Co., Waterford, NY). Radioactivity was then counted in the pellets and supernatants in a Searle Delta 300 liquid scintillation counter (T.M. Analytic, Elk Grove Village, IL) using Liquiscint 121 (National Diagnostics, Sommerville, NJ). In parallel, aliquots of the same synaptosomal suspension were incubated with tritiated water $(0.5 \mu \mathrm{Ci} / \mathrm{ml}$ final concentration; $250 \mu \mathrm{Ci} / \mathrm{gm}$, New England Nuclear, Boston, MA) and ${ }^{14} \mathrm{C}$-polyethylene glycol (MW, $4000 ; 0.13 \mu \mathrm{Ci} / \mathrm{ml}$ final concentration; 1 $\mathrm{mCi} / \mathrm{gm}$, New England Nuclear, Boston, MA) for $1 \mathrm{~min}$. Duplicate samples $(200 \mu \mathrm{l})$ were withdrawn and rapidly centrifuged through silicone oil as described above. Radioactivity was measured both in the supernatants and pellets, and intrasynaptosomal water volume was calculated as given by Rottenberg (1979). The mean value \pm SEM was $4.27 \pm 0.52 \mu \mathrm{l} / \mathrm{mg}$ protein.

Measurement of membrane potential using fluorescence of CC5. Membrane potential-dependent changes in the fluorescence of 3,3'-dipentyl2,2'-oxocarbocyanine (CC5) were measured essentially according to Blaustein and Goldring (1975) with some modifications. Aliquots of synaptosomes, $(3-4 \mathrm{mg}$ protein $/ \mathrm{ml}$ ) stored on ice, were washed once with warm $\left(30^{\circ} \mathrm{C}\right) \mathrm{Krebs}-$ Henseleit-HEPES medium supplemented with $10 \mathrm{~mm}$ glucose and $1.27 \mathrm{mM} \mathrm{CaCl}$ and diluted $1: 10(\mathrm{v} / \mathrm{v})$ with the same medium. Portions ( $1 \mathrm{ml})$ of the latter suspension $(0.35-0.40 \mathrm{mg}$ protein/ $\mathrm{ml}$ ) were placed in a spectrofluorometer $1-\mathrm{ml}$ quartz cuvette at a constant temperature of $30 \pm 1{ }^{\circ} \mathrm{C}$. The contents of the cuvette were mixed continuously with a magnetic bar driven by a stirring device set beneath it. After about 8-10 min of reequilibration, $2.5 \mu \mathrm{l}(1 \mathrm{mg} / \mathrm{ml}$ ethanolic solution) of CC5 dye (Molecular Probes, Eugene, OR) was added. When a constant level of fluorescence signal was attained, usually after 5-7 min incubation, additions of the different test compounds were made as required, from concentrated stock solutions (5-10 $\mu \mathrm{l})$. The fluorescence signal was detected and recorded by a spectrofluorometer (model LS-5, Perkin-Flmer Corp., Norwalk, CT) coupled to a chart recorder. Excitation was at $450 \mathrm{~nm}$ (slit, $2.5 \mathrm{~nm}$ ) and emission at $510 \mathrm{~nm}$ (slit, $5 \mathrm{~nm}$ ) with a response time of 0 .

Extrasynaptosomal $K^{+}$activity. Synaptosomes were preincubated at $3-4 \mathrm{mg} / \mathrm{ml}$ in Krebs-Henseleit-HEPES buffer containing glucose and calcium. The concentration of $\mathrm{KCl}$ in the medium was reduced to 3 mM to increase sensitivity of the measurements. A $1-m$ l aliquot was placed in a stirred chamber thermostated at $30^{\circ} \mathrm{C}$. Potassium concentration in the medium was monitored by an ion-selective electrode (Microelectrodes, Inc., Londonderry, NH). The potassium electrode and a silver/silver chloride reference electrode were connected to a pH meter with a millivolt output. Calibration of the electrode in solutions containing potassium only or incubation medium plus potassium gave a uniform response per decade concentration change $(1,10,100 \mathrm{~mm} \mathrm{KCl})$. Relative calibration was provided by the addition of $1 \mathrm{~mm} \mathrm{KCl}$ at the end of sample incubation.

Measurement of intrasynaptosomal pH by BCECF fluorescence. Intrasynaptosomal $\mathrm{pH}\left(\mathrm{pH}_{i}\right)$ was measured using the fluorescent probe $2^{\prime}, 7^{\prime}$-bis(carboxyethyl)-5,6-carboxyfluorescein (BCECF) essentially according to the methods described previously (Nachschen and Drapeau, 1988; White et al., 1989). The acetoxymethyl ester of $2^{\prime}, 7^{\prime}$ bis(carboxyethyl)-5,6-carboxyfluorescein (BCECF-AM; Molecular Probes, Eugene, OR; $500 \mu \mathrm{M}$ stock dissolved in dimethylsulfoxide) was added $(5 \mu \mathrm{l} / \mathrm{ml})$ to synaptosomes suspended in Krebs-Henseleit-HEPES buffer, $\mathrm{pH} 7.4(5 \mathrm{mg}$ protein $/ \mathrm{ml})$. The suspension was supplemented with $10 \mathrm{~mm}$ glucose and $1.27 \mathrm{~mm} \mathrm{CaCl}$, and incubated for $30 \mathrm{~min}$ at $37^{\circ} \mathrm{C}$ in a shaking water bath to allow loading, hydrolysis, and trapping of BCECF. Finally, in order to remove unloaded or leaked dye, synaptosomes were diluted 10 times with the same warm incubation medium and centrifuged at $10,000 \times g_{a v}$ for $2 \mathrm{~min}$. The pellets were washed again in the same manner, and the final pellet was gently resuspended in the incubation medium $(5 \mathrm{mg}$ protein $/ \mathrm{ml}$ ). Loaded synaptosomes were kept on ice and used within $2 \mathrm{hr}$.

Before each measurement, a 100- $\mu$ l aliquot of the synaptosomal suspension was mixed with $1 \mathrm{ml}$ of warm $\left(30^{\circ} \mathrm{C}\right)$ incubation medium in an Eppendorf tube (1.5 ml capacity) and spun down in a Microcentaur MSE (30 sec, 13,000 $\left.\times g_{\mathrm{av}}\right)$. After gentle resuspension in $1 \mathrm{ml}$ of the incubation medium, synaptosomes were transferred into a fluorometer quartz cuvette. BCECF fluorescence was followed in the same recording spectrofluorometer as described above for $\mathrm{CC} 5$ experiments. Synaptosomes, maintained at $30^{\circ} \mathrm{C}$ with stirring, were incubated for 8-10 min to allow equilibration of their transmembrane ion gradients. Test compounds (5-10 $\mu \mathrm{l}$ from stock solutions) were then added as required by the experimental protocol. The fluorescence signal was detected and recorded with excitation at $505 \mathrm{~nm}$ (slit, $2.5 \mathrm{~nm}$ ) and emission at 530 $\mathrm{nm}$ (slit, $10 \mathrm{~nm}$ ); the response time was 0 .

Calibrations were carried out at the end of each recording by adding $2 \mu \mathrm{l} / \mathrm{ml}$ of nigericin (Sigma Chemical Co., St. Louis, MO; $5 \mathrm{mg} / \mathrm{ml}$ ethanolic stock solution) plus $20 \mu \mathrm{l} / \mathrm{ml}$ of $7.0 \mathrm{M} \mathrm{KCl}$. After stabilization, $\mathrm{pH}$ was measured with a $\mathrm{pH}$ meter, three additions of microliter amounts of $1 \mathrm{~N} \mathrm{HCl}$ were made to lower the $\mathrm{pH}$. Finally Tris base was added to raise the $\mathrm{pH}$. These points were used to construct calibration curves, which were found to be linear in the range of $\mathrm{pH}$ from 5.5 through 8.0.

Measurement of cytosolic free calcium using Quin 2. The concentrations of cytosolic free calcium were measured with the fluorescent probe Quin 2 as described in detail previously (Erecińska and Dagani, 1990). In the experiments without $\mathrm{Na}$ or $\mathrm{Ca}$, all the washing procedures were carried out with buffers in which equimolar choline chloride substituted for $\mathrm{NaCl}$ and $10 \mathrm{mM} \mathrm{MgCl}_{2}$ was added instead of $\mathrm{CaCl}_{2}$.

Extrasynaptosomal amino acid levels. Synaptosomes (1.5 mg protcin/ $\mathrm{ml}$ ) after 5 and $10 \mathrm{~min}$ incubation with shaking in standard buffer at $30^{\circ} \mathrm{C}$ with and without monensin were centrifuged through silicone oil as described above. Deproteinized supernatants were utilized for the determination of amino acid concentrations by HPLC-fluorescence detection of their $o$-phthalaldehyde derivatives (Jarret et al., 1986).

Other procedures. Oxygen consumption, metabolite levels, and uptake of $2-{ }^{3} \mathrm{H}$-deoxyglucose were measured as described previously (Erecińska and Dagani, 1990). Protein content was determined by the biuret reaction using bovine serum albumin as the standard.

\section{Experiments on cells}

C6 glioma cells were cultured and harvested as given by Erecińska and Silver (1986). Cells suspended at 4-5 mg dry weight $/ \mathrm{ml}$ were preincu- 
Table 1. Effects of ouabain and monensin on respiratory rate and lactate production in rat brain synaptosomes

\begin{tabular}{|c|c|c|c|c|c|}
\hline \multirow[b]{2}{*}{ Conditions } & \multicolumn{2}{|c|}{$\begin{array}{l}\text { After } 5 \mathrm{~min} \text { incubation } \\
(\mathrm{nmol} / \mathrm{min} / \mathrm{mg} \text { protein })\end{array}$} & \multicolumn{2}{|c|}{$\begin{array}{l}\text { After } 15 \mathrm{~min} \text { incubation } \\
(\mathrm{nmol} / \mathrm{min} / \mathrm{mg} \text { protein) }\end{array}$} & \multirow{2}{*}{$\begin{array}{l}{ }^{3} \mathrm{H}-2 \text {-deoxyglucose } \\
\text { (fmol/min/mg protein) }\end{array}$} \\
\hline & Oxygen & Lactate & Oxygen & Lactate & \\
\hline Control & $\begin{array}{c}3.64 \pm 0.06 \\
(n=7)\end{array}$ & $\begin{array}{c}0.76 \pm 0.05 \\
(n=4)\end{array}$ & $\begin{array}{l}3.61 \pm 0.05 \\
(n=7)\end{array}$ & $\begin{array}{c}0.76 \pm 0.05 \\
(n=4)\end{array}$ & $\begin{array}{c}15.62 \pm 1.06 \\
(n=3)\end{array}$ \\
\hline Ouabain & $\begin{array}{c}2.99 \pm 0.10^{a} \\
(n=5)\end{array}$ & $\begin{array}{c}0.28 \pm 0.05^{a} \\
(n=3)\end{array}$ & $\begin{array}{c}2.97 \pm 0.12^{a} \\
(n=5)\end{array}$ & $\begin{array}{l}0.28 \pm 0.05^{a} \\
(n=3)\end{array}$ & $\begin{array}{l}8.38 \pm 0.61^{a} \\
(n=3)\end{array}$ \\
\hline Monensin & $\begin{aligned} 6.30 & \pm 0.10^{a} \\
(n & =6)\end{aligned}$ & $\begin{array}{c}9.7 \pm 0.5 \\
(n=6)\end{array}$ & $\begin{array}{c}6.01 \pm 0.20 \\
(n=6)\end{array}$ & $\begin{aligned} 6.00 & \pm 0.19^{a} \\
(n & =6)\end{aligned}$ & $\begin{array}{c}98.87 \pm 7.93^{a} \\
(n=3)\end{array}$ \\
\hline Monensin + ouabain & $\begin{array}{l}3.61 \pm 0.06^{b_{i c}} \\
(n=5)\end{array}$ & $\begin{array}{l}3.97 \pm 0.12^{c} \\
(n=5)\end{array}$ & $\begin{aligned} 3.40 & \pm 0.07^{c} \\
(n & =4)\end{aligned}$ & $\begin{array}{l}2.69 \pm 0.17^{a, b, c} \\
\quad(n=5)\end{array}$ & $\begin{array}{c}66.77 \pm 3.58^{a . c} \\
(n=3)\end{array}$ \\
\hline
\end{tabular}

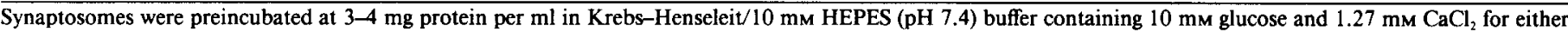

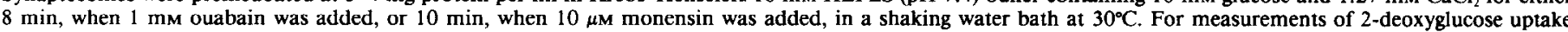

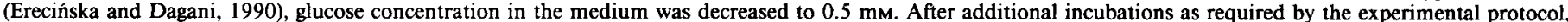

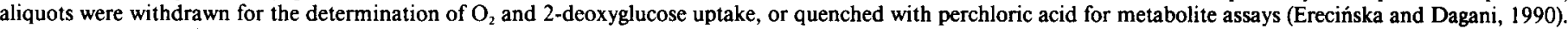

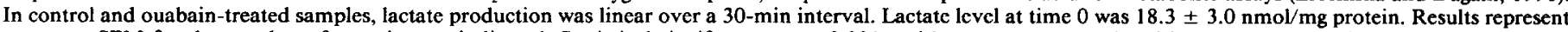

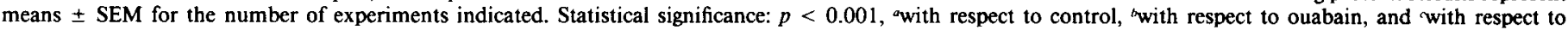
monensin.

bated for $10 \mathrm{~min}$ in Hanks'/10 mm HEPES (pH 7.4) medium, containing $10 \mathrm{~mm}$ glucose, $1.27 \mathrm{mM} \mathrm{CaCl}_{2}$, and $0.4 \%$ bovine serum albumin in a shaking water bath maintained at $37^{\circ} \mathrm{C}$. Test compounds were then added (time 0 ), and the incubation continued for $20 \mathrm{~min}$. At the end of this interval, aliquots were quenched with perchloric acid and used for the measurement of metabolites (Erecińska and Silver, 1986). In experiments in which oxygen uptake was determined, samples were transferred to an oxygen electrode chamber after $10 \mathrm{~min}$ preincubation, and the compounds of interest were added directly while the $\mathrm{O}_{2}$ tension was monitored. Dry weights of cells and the medium were measured for each experiment. Independent determinations on cells suspended in buffer without albumin showed that protein (quantified by the biuret reaction) constituted $91 \pm 2 \%$ of the dry weight.

For measurements of ${ }^{86} \mathrm{Rb}$ uptake, $\mathrm{C} 6$ cells were preincubated at 1$2 \mathrm{mg}$ dry weight $/ \mathrm{ml}$ as described above. After preincubation, aliquots were transferred to $25-\mathrm{ml}$ Erlenmeyer flasks containing various test compounds (ouabain, $1 \mathrm{mM}$; monensin, $10 \mu \mathrm{M}$ ) and $50 \mu \mathrm{M}{ }^{86} \mathrm{RbCl}$ and were further processed as described for synaptosomes. Rates of ${ }^{86} \mathrm{Rb}$ uptake were calculated by linear regression analysis of increase in radioactivity in the pellets. The velocities were found to be the same whether cells were suspended in $5 \mathrm{mM} \mathrm{KCl}$ or $5 \mathrm{~mm} \mathrm{RbCl}$.

Neurons were obtained from fetal mice. Cerebral cortices were removed at 14-17 d of gestation and washed in sterile phosphate-buffered saline (PBS). The tissue was then finely minced, washed twice with PBS, and resuspended in medium consisting of a 1:1 (v/v) mixture of Ham's F12 and Dulbecco's modified Eagle's medium (DMEM) supplemented with $10 \%$ fetal calf serum, $2 \mathrm{~mm}$ glutamine, $200 \mathrm{U} / \mathrm{ml}$ penicillin, and $100 \mu \mathrm{g} / \mathrm{ml}$ streptomycin. Tissue fragments were aspirated with a syringe equipped with a 19-gauge needle, and the resulting cell aggregates were plated onto $30-\mathrm{mm}$ tissue culture dishes previously treated with $2.5 \mu \mathrm{g} /$ $\mathrm{ml}$ poly-D-lysine. Cultures were maintained in a humidified atmosphere of $5 \% \mathrm{CO}_{2}$ in air and, after $4 \mathrm{~d}$, were replenished with fresh medium. Three to five days later, they were washed with PBS and supplied with a maintenance medium consisting of a 1:1 mixture (v/v) of Ham's F12 and DMEM supplemented with $2 \mathrm{mM}$ L-glutamine, $0.25 \%$ fetal calf serum, $5 \mu \mathrm{g} / \mathrm{ml}$ insulin, $200 \mathrm{U} / \mathrm{ml}$ penicillin, and $100 \mu \mathrm{g} / \mathrm{ml}$ streptomycin. The small amount of fetal calf serum in the medium was sufficient to maintain neuronal growth, while development of non-neuronal cells was inhibited and eventually halted. Subsequent medium replacement was carried out twice weekly, and neurons were used for experiments after 2-4 weeks. Intracellular measurements were made from randomly selected neurons that constituted more than $90 \%$ of the cell population. Individual cells from which recordings were made were positively identified as neurons by staining for Nissl substance after fixation with $10 \%$ formalin solution at the end of the measuring period.

Intracellular $\mathrm{Na}^{+}, \mathrm{K}^{+}, \mathrm{Ca}^{2+}$, and $\mathrm{H}^{+}$and transmembrane electrical potentials were measured at $37^{\circ} \mathrm{C}$ with either double-barreled or triplebarreled microelectrodes (Erecińska and Silver, 1986) using calibration procedures described in detail by Silver and Erecińska (1990).

Statistical evaluation of the data was performed using either Student's $t$ test or $t$ statistics with correction for multiple comparisons.

\section{Results}

\section{Synaptosomes}

\section{Effect of monensin on respiration and lactate production}

Preliminary experiments established that $10-20 \mu \mathrm{M}$ monensin gave maximal stimulation of respiration and lactate production; hence, this concentration of the antibiotic was used in most subsequent studies.

Table 1 shows that addition of monensin induced a large, almost twofold, increase in oxygen consumption. Both the control and the stimulated rates remained constant over 15-30 min incubation. The stimulation of respiration by monensin was almost completely abolished by treatment with $1 \mathrm{~mm}$ ouabain.

The rate of lactate synthesis also rose markedly with monensin addition (Table 1). During the first $5 \mathrm{~min}$ of incubation, the overall lactate generation was increased 12.8 times, and the ouabain-sensitive portion, 12 times. However, in contrast to respiration, aerobic glycolysis remained high when both monensin and ouabain were present. The monensin-stimulated rate of lactate production declined with time: it was much slower when measured after $15 \mathrm{~min}$ than at $5 \mathrm{~min}$ incubation. By contrast, in control and ouabain-treated samples lactate generation was linear over a 30 -min interval.

To confirm the enhancement of the glycolytic flux, as evaluated by the amount of lactate formed, uptake of radioactive 2-deoxyglucose, a substrate for the glucose transporter in synaptosomal plasma membrane (Diamond and Fishman, 1973; Erecińska, 1989), was determined under the same conditions. The results (Table 1) fully confirm those obtained from estimates of lactate levels: essentially, the same pattern was observed of stimulation by monensin and inhibition by ouabain.

Rates of pyruvate production were also measured with and without monensin. At time 0 (i.e., after $10 \mathrm{~min}$ preincubation), synaptosomal suspensions contained $1.43 \pm 0.31 \mathrm{nmol} / \mathrm{mg}$ protein of pyruvate; the amount was $2.61 \pm 0.17 \mathrm{nmol} / \mathrm{mg}$ protcin after $30 \mathrm{~min}$ incubation, giving a rate of $0.04 \mathrm{nmol} / \mathrm{min} / \mathrm{mg}$ protein. With monensin, the levels were $5.02 \pm 0.3 \mathrm{nmol} / \mathrm{mg}$ protein after $5 \mathrm{~min}$ and $7.97 \pm 0.5 \mathrm{nmol} / \mathrm{mg}$ protein after 15 $\mathrm{min}$, which corresponds to a rate of 0.72 and $0.44 \mathrm{nmol} / \mathrm{min} /$ $\mathrm{mg}$ protein, respectively, for the two intervals. The [lactate]/ [pyruvate] ratios were not affected by addition of the antibiotic 


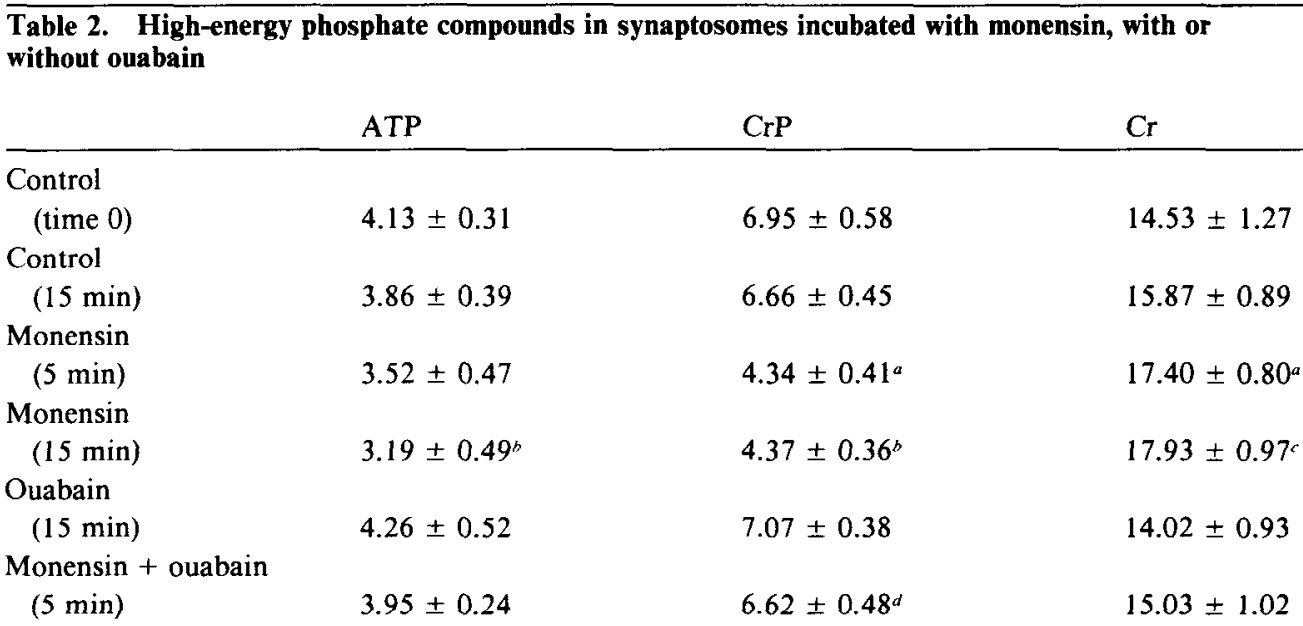

ATP, CrP, and $\mathrm{Cr}$ (nmol/mg protein) were measured by standard enzymatic techniques (Erecińska and Dagani, 1990) on synaptosomes incubated as described in Table 1 notes. Ouabain concentration was $1 \mathrm{~mm}$, and that of monensin, 10 $\mu \mathrm{M}$. Results represent means \pm SEM for three experiments. Statistical significance: ${ }^{a} p<0.05$ versus 10 min preincubation (time 0 ), ${ }^{b} p<0.05$ versus 15 min control, $c p<0.01$ versus 15 min control, ${ }^{d} p<0.05$ versus monensin.

$(12.8 \pm 0.8$ at time $0,13.3 \pm 0.7$ after 5 min incubation, and $13.2 \pm 1.3$ after $15 \mathrm{~min}$ incubation with monensin).

Synaptosomal energy level in the presence of monensin

The intrasynaptosomal levels of ATP, creatine phosphate $(\mathrm{CrP})$ and creatine $(\mathrm{Cr})$ were measured after 5 and 15 min incubation with monensin and either with or without ouabain. Small decreases in $\mathrm{CrP}$ and ATP and increases in $\mathrm{Cr}$ were observed in the presence of the antibiotic (Table 2), which could already be detected after $5 \mathrm{~min}$ incubation. These changes were prevented, to a large extent, by addition of ouabain.

\section{Effect of monensin on synaptosomal Na pump}

To provide evidence for the supposition that monensin-induced rise in internal $\left[\mathrm{Na}^{+}\right]$stimulates pump activity, rates of ${ }^{86} \mathrm{Rb}$ uptake were measured after addition of the antibiotic, with and without ouabain. At low concentrations $(<4 \mu \mathrm{M})$, monensin increased ouabain-sensitive uptake of the tracer. The rate was $17.5 \pm 0.5 \mathrm{fmol} / \mathrm{min} / \mathrm{mg}$ protein in control samples, and it rose to $27.9 \pm 0.8 \mathrm{fmol} / \mathrm{min} / \mathrm{mg}$ protein with $4 \mu \mathrm{M}$ monensin. When $1 \mathrm{~mm}$ ouabain was added, the velocities were the same with and without the antibiotic $(7.8+0.2$ vs. $8.2 \pm 0.4 \mathrm{fmol} / \mathrm{min} / \mathrm{mg}$ protein, respectively). At higher levels of monensin, progressive and large membrane depolarization was observed, which precluded the use of the method for the measurement of the pump activity.

\section{Monensin-induced depolarization of synaptosomal plasma membrane}

The effect of monensin on plasma membrane potential was measured using two methods: equilibrium distribution of ${ }^{86} \mathrm{Rb}$ (not shown) and increase in fluorescence of the carboxycyanine dye CC5 (Fig. 1). Both methods yielded consistent results in that they showed that the antibiotic induced a concentrationdependent depolarization of synaptosomes. Maximal decrease in membrane potential was observed with 10-20 $\mu \mathrm{M}$ monensin, and it was as large as, or even larger than, that seen with saturating concentration of veratridine $(40-50 \mu \mathrm{M})$. By comparing the effects of monensin with those of high [KCl], approximate values of membrane potential could be calculated. Figure 1 shows that $20 \mu \mathrm{M}$ monensin gave greater increase in fluorescence than $45 \mathrm{~mm} \mathrm{KCl}$. Because at the latter $\left[\mathrm{K}^{+}\right]_{e}$ the $\left[\mathrm{K}^{+}\right]_{i} /\left[\mathrm{K}^{+}\right]_{e}$ is about 2 (Erecińska et al., 1983), the calculated $\mathrm{K}^{+}$diffusion potential is less than $-20 \mathrm{mV}$.

To confirm the finding that monensin causes depolarization of the synaptosomal plasma membrane, the concentration of potassium in the medium was measury with a $\mathrm{K}^{+}$-sensitive electrode. Figure $2 A$ shows that addition of increasing amounts of monensin resulted in a progressive rise in $\left[\mathrm{K}^{+}\right]_{e}$. Maximum leakage was attained with 10-20 $\mu \mathrm{M}$ monensin, and it was not increased further by administration of $50 \mu \mathrm{M}$ veratridine (not

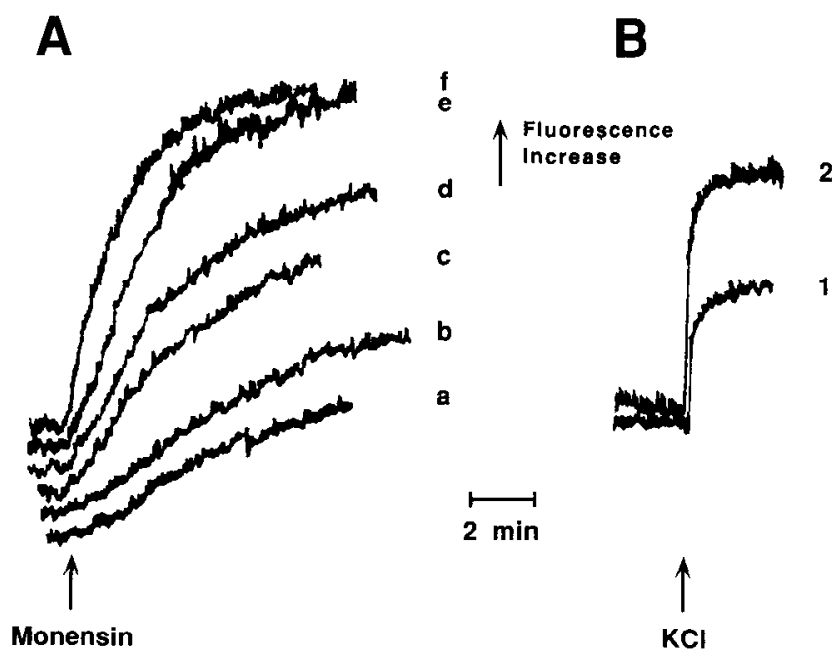

Figure 1. Monensin-induced changes in membrane potential measured by fluorescence of $\mathrm{CC} 5$ dye. Experimental conditions are described in Materials and Methods. $A$, Monensin concentrations were (recordings $a-f) 0.2,0.4,1.25,2.5,10$, and $20 \mu \mathrm{M} . B,[\mathrm{KCl}]$ was $25 \mathrm{~mm}$ in recording 1 and $45 \mathrm{~mm}$ in recording 2 . The initial fluorescence was approximately the same in all experiments, but the traces were offset in the figure to avoid overlap. 

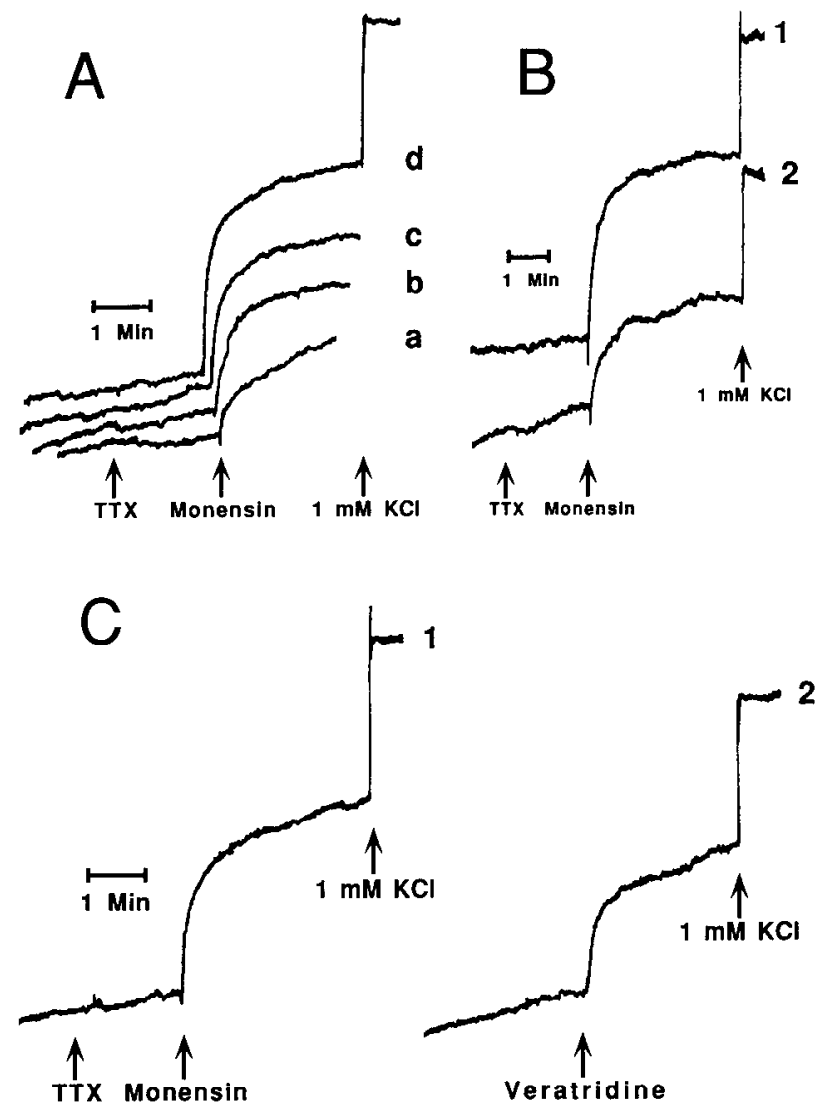

Figure 2. A, Changes in extrasynaptosomal potassium levels with increasing monensin concentration. Tetrodotoxin $(T T X ; 0.15 \mu \mathrm{M})$, monensin $(5,10,20$, and $40 \mu \mathrm{M}$, recordings $a-d$, respectively), and $\mathrm{KCl}$ were added as indicated. The initial level of $\mathrm{K}^{+}$was about the same in all experiments, and the traces were offset in the figure to avoid overlap. $B$, Effect of sodium withdrawal on monensin-induced increase in external potassium concentration. Recording 1, control; recording 2, 140 mu choline chloride replaces $\mathrm{NaCl}$. Tetrodotoxin $(T T X ; 0.15 \mu \mathrm{M})$, monensin $(20 \mu \mathrm{M})$, and $\mathrm{KCl}$ were added as indicated. $C$, Comparison between the effects of monensin (recording 1 ) and veratridine (recording 2 ) on potassium release. Tetrodotoxin $(T T X ; 0.15 \mu \mathrm{M})$, monensin $(20$ $\mu \mathrm{M})$, veratridine $(50 \mu \mathrm{M})$, and $\mathrm{KCl}$ were added as indicated. In all experiments $(A-C),\left[\mathrm{K}^{+}\right]_{\text {e }}$ was measured with a $\mathrm{K}^{+}$-sensitive electrode as described in Materials and Methods. shown). The release of potassium at saturating [monensin] was as large as, or larger than, that with $50 \mu \mathrm{M}$ veratridine (Fig. 2C). It was unaffected by elimination of external calcium (and addition of $10 \mathrm{mM} \mathrm{Mg}^{2+}$ ) and addition of either $10 \mathrm{~mm}$ tetraethylammonium or $1 \mathrm{mM} \mathrm{BaCl}$. Similarly, replacement of chloride with gluconate or addition of $1 \mathrm{~mm}$ 4-acetamido-4'-isothiocyanostilebene-2,2'-disulfonic acid (SITS) did not alter the amount of potassium released by 10-20 $\mu \mathrm{M}$ monensin. By contrast, substitution of $\mathrm{Na}^{+}$with choline substantially reduced the rise in $\left[\mathrm{K}^{+}\right]_{e}$ (Fig. 2B).

Consistent with the results obtained with the $\mathrm{K}^{+}$-sensitive electrode, tetraethylammonium and barium chloride did not affect changes in $\mathrm{CC} 5$ fluorescence induced by monensin. On the other hand, when $\mathrm{NaCl}$ was replaced with choline chloride, addition of the antibiotic causcd an abrupt but small decline in fluorescence that was followed by a slow rise whose magnitude was much less than that seen at the same [monensin] in the sodium-containing media (data not shown). Choline chloride itself did not appear to influence performance of the dye.

\section{Effect of monensin on intrasynaptosomal calcium and protons}

The concentration of free cylosolic calcium was measured from changes in fluorescence of the indicator Quin 2. In control synaptosomes, $\left[\mathrm{Ca}^{2+}\right]$ was $256 \pm 12 \mathrm{nM}($ mean $\pm \mathrm{SEM} ; n=10)$, and it fell to $91 \pm 6(n=7)$ when external calcium was eliminated and replaced with $10 \mathrm{~mm}$ magnesium. Addition of $20 \mu \mathrm{M}$ monensin caused a rise in $\left[\mathrm{Ca}^{2+}\right]_{i}$ (Fig. $\left.3 A\right)$ to $765 \pm 15 \mathrm{~nm}(n=$ $4)$; this compares with a concentration of $563 \pm 19 \mathrm{nм}(n=6)$ obtained in the presence of $50 \mu \mathrm{M}$ veratridine. In the absence of external calcium, the monensin-induced rise in the internal concentration of this cation was very small (Fig. $3 B$ ). Similarly, elimination of sodium substantially reduced the rise in $\left[\mathrm{Ca}^{2+}\right]_{i}$ (Fig. 3C).

Intrasynaptosomal $\mathrm{pH}$, estimated from changes in fluorescence of BCECF, was 7.15-7.20 under control conditions in the $\mathrm{Na}^{+}$-containing medium (Fig. 4). It was, however, much lower in the absence of sodium, as would be expected of organelles in which the $\mathrm{Na}^{+} / \mathrm{H}^{+}$exchanger is the major mechanism responsible for $\mathrm{H}^{+}$extrusion (Jean et al., 1985). Addition of monensin caused an abrupt internal alkalinization that, surprisingly, saturated at very low [monensin], 1-2 $\mu \mathrm{M}$ (Fig. 4A). Veratridine had no effect on $\mathrm{pH}_{i}$, and it did not prevent the fall in $\left[\mathrm{H}^{+}\right]_{i}$
Figure 3. Monensin-induced changes in intrasynaptosomal calcium levels. $\left[\mathrm{Ca}^{2+}\right]$, was measured with the fluorescent probe Quin 2. After loading, the resuspended synaptosomes were equilibrated for $10 \mathrm{~min}$ in an appropriate buffer containing $10 \mathrm{~mm}$ glucose. Changes in fluorescence were followed after addition of $20 \mu \mathrm{M}$ monensin. $A$, Standard Krebs-Henseleit-HEPES buffer, containing $1.27 \mathrm{mM} \mathrm{CaCl} . B$, $\mathrm{MgCl}_{2}(10 \mathrm{~mm})$ instead of $\mathrm{CaCl}_{2}$. $C$, $\mathrm{NaCl}$ replaced with choline chloride; $\mathrm{CaCl}_{2}$ was $1.27 \mathrm{~mm}$. At the end of each experiment, a calibration was performed. $F_{\min }$ was recorded after addition of $2 \mathrm{~mm}$ EGTA, $10 \mathrm{~mm}$ Tris, and $1 \%$ Triton X-100. $F_{\max }$ was obtained upon addition of excess $\mathrm{CaCl}_{2}(4 \mathrm{~mm})$.

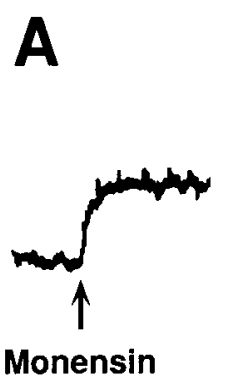

B

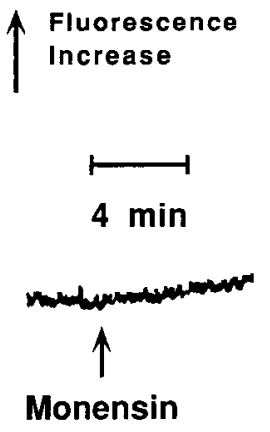

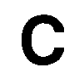

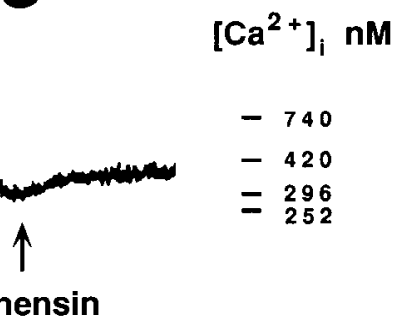

$-100$ 
Table 3. Changes in extrasynaptosomal amino acid levels after incubation with $20 \mu \mathrm{M}$ monensin

\begin{tabular}{llr} 
& $\Delta 5 \mathrm{~min}$ & \multicolumn{1}{c}{$\Delta 10 \mathrm{~min}$} \\
\hline Aspartate & $3.52 \pm 0.29$ & $4.60 \pm 0.46$ \\
Glutamate & $9.55 \pm 0.35$ & $14.24 \pm 0.49$ \\
GABA & $1.56 \pm 0.05$ & $2.46 \pm 0.08$
\end{tabular}

Conditions of experiments are given in Materials and Methods. Values represent means \pm SEM for seven experiments and are the differences between controls and samples incubated with monensin for the number of minutes indicated (nmol/ mg protein).

induced by monensin (Fig. $4 B$ ). In contrast, replacement of sodium with choline eliminated the rise in $\mathrm{pH}$ that followed addition of the antibiotic (Fig. 4C).

\section{Monensin-induced release of amino acids}

After $10 \mathrm{~min}$ preincubation, the intrasynaptosomal levels of aspartate, glutamate, and GABA were $23.6 \pm 0.3,42.2 \pm 2.0$, and $8.6 \pm 0.2 \mathrm{nmol} / \mathrm{mg}$ protein, respectively; the corresponding levels in the medium were $0.8 \pm 0.1,1.8 \pm 0.3$, and $0.4 \pm 0.1$ $\mu \mathrm{M}$. Monensin at $20 \mu \mathrm{M}$ caused release of GABA, aspartate, and glutamate (Table 3); other amino acids were not affected. Moreover, there were no changes in either the internal or external levels of aspartate, glutamate, and GABA in samples incubated without the antibiotic.

The monensin-triggered release was unaltered by calcium withdrawal or addition of $5 \mu \mathrm{M}$ tetrodotoxin (not shown).

\section{C6 cells}

\section{Effect of monensin on respiration and lactate production}

The rates of $\mathrm{O}_{2}$ uptake and lactate production were measured in suspensions of $\mathrm{C} 6$ cells treated with $10 \mu \mathrm{M}$ monensin. This concentration was used because at higher levels the antibiotic did not cause any further increase in respiration or lactate generation. Table 4 shows that the behavior of glioma cells differed from that of synaptosomes: the stimulation of $\mathrm{O}_{2}$ consumption was barely detectable (less than $10 \%$ rise), whereas the already high glycolytic flux was doubled. On the other hand, the responses to ouabain were rather similar in the two systems; in C6 cells the glycoside reduced respiration by about $20 \%$ and lactate production by $27 \%$. With both monensin and ouabain present, the rate of aerobic glycolysis remained elevated as compared to control or ouabain-treated samples.

Rates of pyruvate production were determined in the same incubation mixtures in which lactate generation was measured. The values obtained were $0.42 \pm 0.03 \mathrm{nmol} / \mathrm{min} / \mathrm{mg}$ dry weight
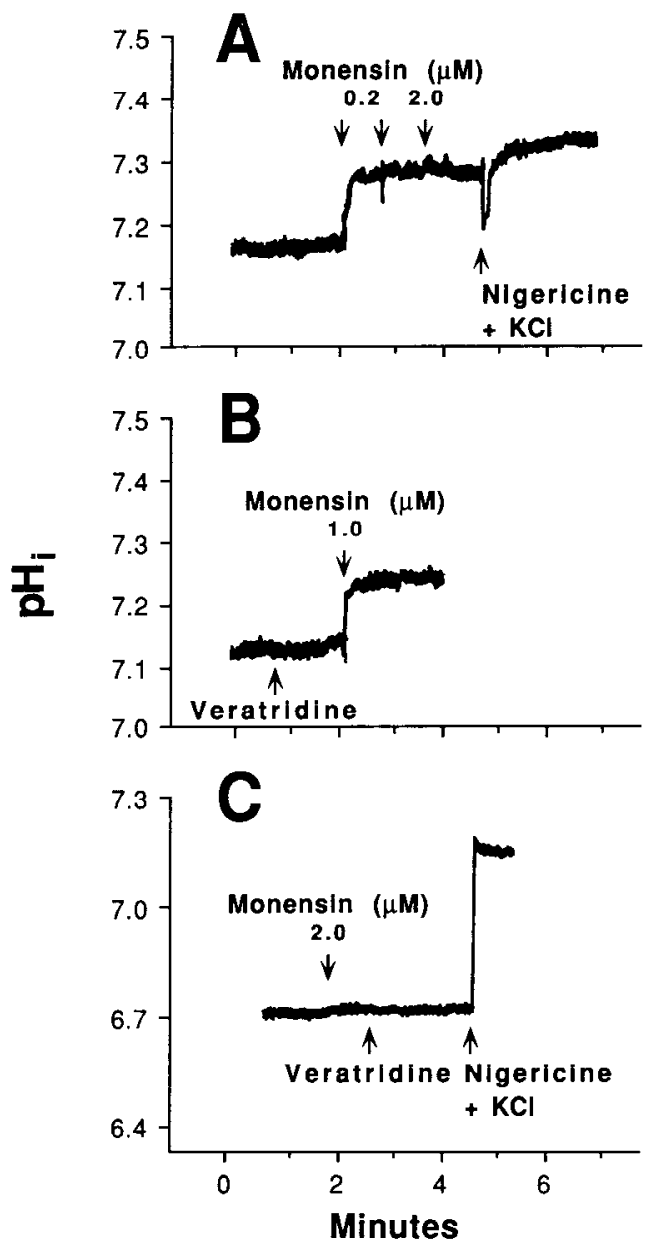

Figure 4. Changes in $\mathrm{pH}_{i}$ induced by monensin. $\mathrm{pH}_{i}$ was measured using the fluorescent probe BCECF as described in Materials and Methods. In $A$ and $B$, synaptosomes were incubated in standard KrebsHenseleit-HEPES buffer; in $C, \mathrm{NaCl}$ was replaced with equimolar concentration of choline chloride. Veratridine was added at $50 \mu \mathrm{M}$; nigericin, at $10 \mu \mathrm{g} / \mathrm{ml}$; and $\mathrm{KCl}$, at $140 \mathrm{~mm}$.

without monensin and $0.93 \pm 0.06 \mathrm{nmol} / \mathrm{min} / \mathrm{mg}$ dry weight in its presence. From the measured levels of lactate and pyruvate, their ratios under various conditions were calculated. The [lactate]/[pyruvate] was $10.8 \pm 0.8$ at time $0,12.8 \pm 1.0$ after $20 \mathrm{~min}$ of control incubation, and $12.8 \pm 0.5$ after $20 \mathrm{~min}$ treatment with monensin.

Table 4. High-energy phosphate compounds, rate of respiration, and lactate production in C6 cells incubated with monensin, with or without ouabain

\begin{tabular}{lllllrr} 
& ATP & CrP & Cr & CrP/Cr & Oxygen \\
\hline Control & $19.5 \pm 1.5$ & $18.0 \pm 0.8$ & $8.49 \pm 0.41$ & $2.12 \pm 0.03$ & $6.55 \pm 0.08$ & $10.00 \pm 1.31$ \\
Ouabain & $22.2 \pm 1.7$ & $20.7 \pm 0.5^{a}$ & $7.79 \pm 0.15$ & $2.65 \pm 0.03^{a}$ & $5.56 \pm 0.05^{a}$ & $7.32 \pm 0.73$ \\
Monensin & $20.9 \pm 1.7$ & $17.4 \pm 0.7$ & $9.80 \pm 0.29^{a}$ & $1.77 \pm 0.02^{a}$ & $6.86 \pm 0.04^{a}$ & $20.84 \pm 1.00^{a}$ \\
Monensin + ouabain & $22.3 \pm 1.8$ & $20.2 \pm 0.4^{c}$ & $7.90 \pm 0.12^{c}$ & $2.56 \pm 0.02^{a, c}$ & $5.54 \pm 0.06^{a, c}$ & $13.46 \pm 0.81^{b, c}$
\end{tabular}

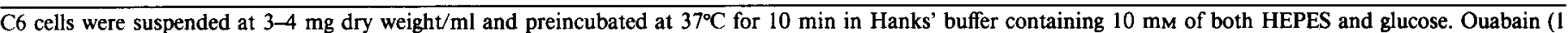

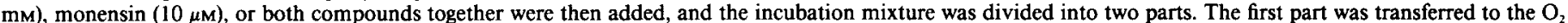

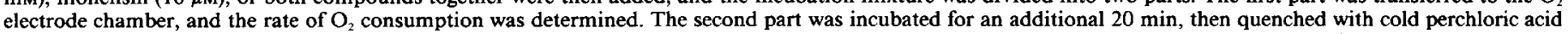

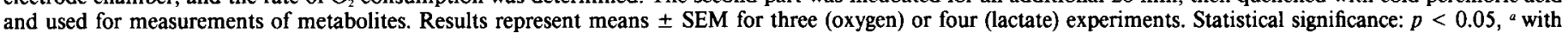

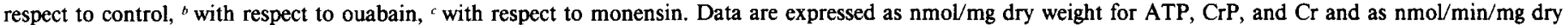
weight for oxygen and lactate. 

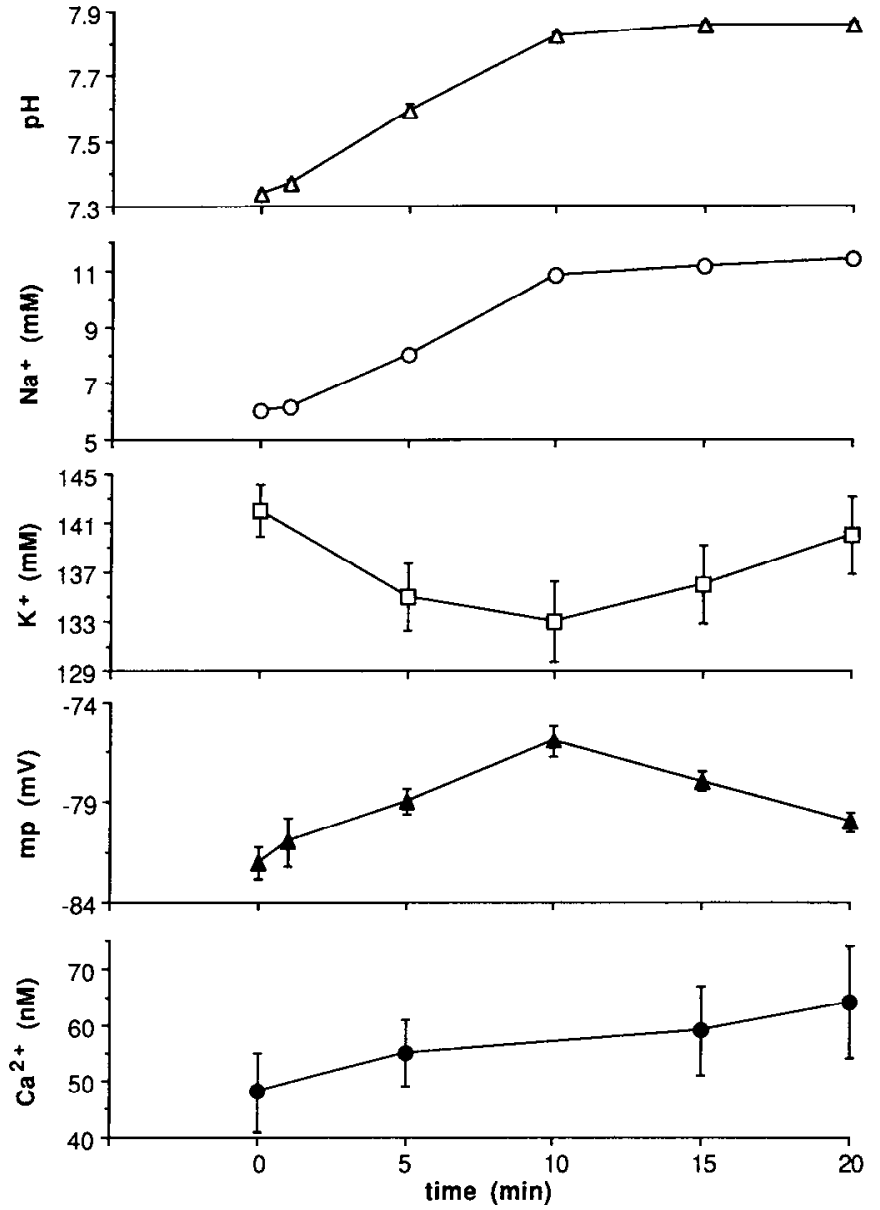

Figure 5. Time courses of the effect of monensin on intracellular cation concentrations and membrane potentials in $\mathrm{C} 6$ cells. $\mathrm{C} 6$ cells bathed in Hanks' medium containing $10 \mathrm{~mm}$ HEPES ( $\mathrm{pH} 7.4$ ) and $10 \mathrm{~mm}$ glucose were impaled with ion-selective microelectrodes. Baseline values of $\left[\mathrm{Na}^{+}\right],\left[\mathrm{H}^{+}\right],\left[\mathrm{K}^{+}\right]$, and $\left[\mathrm{Ca}^{2+}\right]$ and membrane potentials were recorded and are shown as corresponding to time 0 . The regular medium was gently suctioned off, such as not to disturb the microelectrodes placed inside the cell, and replaced with one containing $10 \mu \mathrm{M}$ monensin. The recordings were continued for the next $20 \mathrm{~min}$. Values were calculated at $1,5,10,15$, and $20 \mathrm{~min}$ after addition of monensin and represent means \pm SEM for number of cells indicated: membrane potential $(\mathrm{mp})$, $n=12 ; \mathrm{pH}$ and $\mathrm{Na}^{+}, n=6 ; \mathrm{Ca}^{2+}, n=4 ; \mathrm{K}^{+}, n=3$. SEM is not shown when its magnitude is smaller than the size of the symbol.

\section{Effects of monensin on ${ }^{86} \mathrm{Rb}$ fluxes}

The rate of ${ }^{86} \mathrm{Rb}$ uptake was $19.03 \pm 2.3 \mathrm{nmol} / \mathrm{min} / \mathrm{mg}$ dry weight in the absence of monensin and $33.12 \pm 1.9 \mathrm{nmol} / \mathrm{min} /$ mg dry weight in its presence. The corresponding values with ouabain were $6.01 \pm 0.3$ and $6.53 \pm 0.6 \mathrm{nmol} / \mathrm{min} / \mathrm{mg}$ dry weight (means \pm SEM for three experiments).

\section{Energy level in C6 cells treated with monensin}

The concentrations of ATP, CrP, and $\mathrm{Cr}$ in $\mathrm{C} 6$ cells are considerably higher than in synaptosomes; hence, alterations induced by stimulation or inhibition of the $\mathrm{Na} / \mathrm{K}$ pump can be monitored easily. Table 4 shows that $10 \mu \mathrm{M}$ monensin decreased the $[\mathrm{CrP}] /[\mathrm{Cr}]$, indicative of a fall in $[\mathrm{ATP}]_{\text {rree }} /[\mathrm{ADP}]_{\text {free }}$, while ouabain had the opposite effect. Addition of the glycoside together with monensin reversed the changes in the $[\mathrm{CrP}] /[\mathrm{Cr}]$ caused by addition of the antibiotic. Alterations in the level of ATP were small and statistically nonsignificant. Such behavior
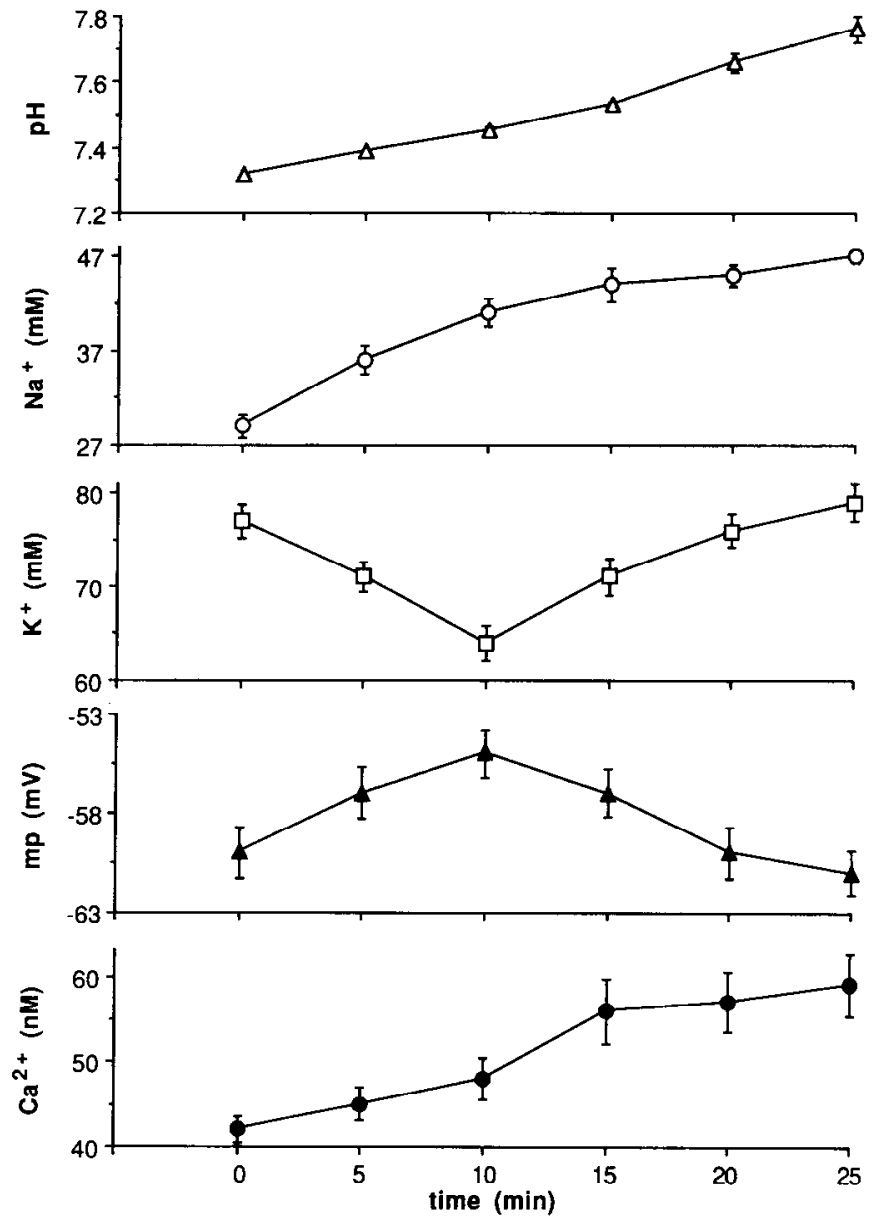

Figure 6. Time courses of the effect of monensin on intracellular cation concentrations and membrane potentials in cultured neurons. Experiments were performed in a manner identical to that described for C6 cells in Figure 5. The number of cells from which the recordings were made are as follows: membrane potential $(m p), n=16 ; \mathrm{Na}^{+}$and $\mathrm{pH}$, $n=6 ; \mathrm{K}^{+}$and $\mathrm{Ca}^{2+}, n=4$. Error bars are as in Figure 5 .

is expected in cells in which the $\mathrm{CrP} / \mathrm{Cr}$ system minimizes the short-term fluctuation in the trinucleotide concentration (Meyer et al., 1984; Erecińska and Silver, 1989).

\section{Changes in intracellular ions induced by monensin in C6 cells}

Changes in the intracellular concentrations of $\mathrm{H}^{+}, \mathrm{Na}^{+}, \mathrm{K}^{+}$, and $\mathrm{Ca}^{2+}$ and in the membrane electrical potential that follow addition of $10 \mu \mathrm{M}$ monensin are shown in Figure 5 . It can be seen that the antibiotic caused internal alkalinization and a parallel rise in $\left[\mathrm{Na}^{+}\right]_{i}$, as expected. The changes were already visible after $1 \mathrm{~min}$ exposure and reached a plateau at about $10 \mathrm{~min}$. Concomitant with the alterations in $\left[\mathrm{Na}^{+}\right]_{i}$ and $\left[\mathrm{H}^{+}\right]_{i}$, there was a small membrane depolarization that reached a maximum of about $6-\mathrm{mV}$ decrease after $10 \mathrm{~min}$ treatment with monensin. Thereafter, the membrane gradually repolarized, and the electrical potential returned to its original value at $20-25 \mathrm{~min}$. The decrease in membrane potential occurred simultaneously with a loss of potassium from cells, which was greatest at $10 \mathrm{~min}$, that is, at the point when depolarization was largest. However, the loss of $\mathrm{K}^{+}$was transient and was followed by the reaccumulation of the cation to its original value at $20 \mathrm{~min}$. The alterations in intracellular calcium were small and slow. After 20 min treatment with monensin, the $\left[\mathrm{Ca}^{2+}\right]_{i}$ increased by less than twofold. 


\begin{tabular}{|c|c|c|c|c|c|}
\hline Conditions & $\mathrm{pH}$ & $\mathrm{Na}^{+}(\mathrm{mM})$ & $\mathrm{K}^{+}(\mathrm{mM})$ & $\mathrm{Ca}^{2+}(\mathrm{nM})$ & $E(\mathrm{mV})$ \\
\hline Control & $\begin{array}{c}7.32 \pm 0.01 \\
(n=5)\end{array}$ & $\begin{array}{c}6.3 \pm 0.1 \\
(n=4)\end{array}$ & $\begin{array}{c}139 \pm 1 \\
(n=3)\end{array}$ & $\begin{array}{c}40.0 \pm 2.4 \\
(n=6)\end{array}$ & $\begin{array}{r}-83.0+0.8 \\
(n=15)\end{array}$ \\
\hline \multicolumn{6}{|l|}{ Ouabain } \\
\hline $10 \mathrm{~min}$ & $\begin{array}{c}7.30 \pm 0.01 \\
(n=5)\end{array}$ & $\begin{array}{c}26.9 \pm 0.8 \\
(n=4)\end{array}$ & $\begin{array}{r}114 \pm 3 \\
(n=3)\end{array}$ & $\begin{array}{c}51.0 \pm 1.5 \\
(n=6)\end{array}$ & $\begin{aligned}-74.0 & \pm 0.6 \\
(n & =13)\end{aligned}$ \\
\hline $20 \mathrm{~min}$ & $\begin{array}{c}7.28 \pm 0.02 \\
(n=5)\end{array}$ & $\begin{array}{c}37.7 \pm 0.7 \\
(n=4)\end{array}$ & $\begin{array}{r}103 \pm 3 \\
(n=3)\end{array}$ & $\begin{array}{c}64.3 \pm 1.4 \\
(n=6)\end{array}$ & $\begin{array}{r}-63.0 \pm 0.6 \\
(n=13)\end{array}$ \\
\hline Control & $\begin{array}{c}7.32 \pm 0.01 \\
(n=5)\end{array}$ & $\begin{array}{c}6.3 \pm 0.1 \\
(n=3)\end{array}$ & $\begin{array}{l}144 \\
\quad(n=2)\end{array}$ & $\begin{array}{c}28.0 \pm 4.0 \\
(n=4)\end{array}$ & $\begin{array}{c}-83.0 \pm 1.0 \\
(n=7)\end{array}$ \\
\hline \multicolumn{6}{|c|}{ Monensin + ouabain } \\
\hline $10 \mathrm{~min}$ & $\begin{array}{c}7.93 \pm 0.08 \\
(n=5)\end{array}$ & $\begin{array}{c}30.2 \pm 1.2 \\
(n=3)\end{array}$ & $\begin{array}{l}110 \\
(n=2)\end{array}$ & $\begin{array}{c}39.0 \pm 5.0 \\
(n=4)\end{array}$ & $\begin{aligned} &-69.0 \pm 1.7 \\
&(n=7)\end{aligned}$ \\
\hline $20 \mathrm{~min}$ & $\begin{array}{c}8.27 \pm 0.08 \\
(n=5)\end{array}$ & $\begin{array}{c}38.1 \pm 0.6 \\
(n=3)\end{array}$ & $\begin{array}{l}103 \\
(n=2)\end{array}$ & $\begin{array}{c}43.0 \pm 6.0 \\
(n=4)\end{array}$ & $\begin{array}{c}-59.0 \pm 1.4 \\
(n=7)\end{array}$ \\
\hline
\end{tabular}

C6 cells bathed in Hanks' buffer were impaled with microelectrodes, and baseline values of ion concentrations and membrane potentials were recorded as controls. Medium was then replaced very rapidly to the one containing either 1 mM ouabain or $1 \mathrm{~mm}$ ouabain plus $10 \mu \mathrm{M}$ monensin, and recordings were continued for the next 20 min. Readings obtained at 10 and 20 min are shown. Values are means \pm SEM for the number of cells penetrated.

Intracellular ion concentrations were also measured in $\mathrm{C} 6$ cells incubated with ouabain alone and with monensin plus ouabain. Changes that occurred after 10 and 20 min of treatment are displayed in Table 5 . It can be seen that addition of ouabain caused a loss of $\mathrm{K}^{+}$from and a gain of $\mathrm{Na}^{+}$into cells; the membrane potential declined in parallel with the collapse of ion gradients. Internal $\mathrm{pH}$ showed little change, and there was a small, less than twofold, rise in $\left[\mathrm{Ca}^{2+}\right]_{i}$.

Administration of ouabain together with monensin gave alterations very similar to those produced with the glycoside alone, except there was a large internal alkalinization. The rise in intracellular $\mathrm{pH}$ was greater than that which occurred with monensin alone.

\section{Neurons}

The alterations in intracellular ions and membrane potential caused by addition of monensin to cultured neurons were qualitatively very similar to those in C6 cells, in spite of the different initial levels of internal sodium and potassium (Fig. 6). There was a loss of $\mathrm{H}^{+}$from and a gain of $\mathrm{Na}^{+}$by cells, while a small reduction in $\left[\mathrm{K}^{+}\right]_{i}$ was accompanied by membrane depolarization. The latter was reversible, and by $20 \mathrm{~min}$ incubation with the antibiotic, $\left[\mathrm{K}^{+}\right]_{i}$ and membrane potentials returned to their original values. By $25 \mathrm{~min}$, a hyperpolarization of $2-3 \mathrm{mV}$ was noted in some neurons, and it was accompanied by an increase in $\left[\mathrm{K}^{+}\right]_{i}$ by $2-4 \mathrm{~mm}$ over the starting, pre-monensin level. The rise in $\left[\mathrm{Ca}^{2+}\right]_{i}$ was small and slow.

Addition of $1 \mathrm{~mm}$ ouabain to neurons treated with monensin caused a much larger increase in $\left[\mathrm{Na}^{+}\right]_{i}$ and more pronounced decreases in $\left[\mathrm{H}^{+}\right]_{i},\left[\mathrm{~K}^{+}\right]_{i}$, and mcmbranc potentials. Within 25 $\min ,\left[\mathrm{Na}^{+}\right]_{i}$ rose to $70-75 \mathrm{~mm},\left[\mathrm{~K}^{+}\right]_{i}$ declined to $40-45 \mathrm{~mm}$, membrane potential fell to $30-32 \mathrm{mV}$, and pH increased to $8.0-$ 8.2. Interestingly, when the plasma membrane depolarized to -40 to $-45 \mathrm{mV},\left[\mathrm{Ca}^{2+}\right]_{i}$ began to change rapidly and reached a level of 120-150 nM at 20-25 min incubation with ouabain plus monensin (data not shown).

\section{Discussion}

Effects of internal $p H$ on ATP production

As seen from the results presented in this article, addition of monensin to cultured neurons, C6 cells, and synaptosomes caus- es intracellular alkalinization, in agreement with the data obtained on other systems (e.g., Grinstein and Goetz, 1985; Siffert and Akkerman, 1989). The fall in $\left[\mathrm{H}^{+}\right]$stimulates glycolysis directly, as demonstrated by the findings (Tables 1,4) that increased rates of lactate production and 2-deoxyglucose uptake persist in the presence of ouabain. The activation of glycolysis involves two mechanisms. The first is through deinhibition of phosphofructokinase by the fall in proton concentration (Trivedi and Danforth, 1966). The second is mediated by the $\mathrm{CrP} /$ $\mathrm{Cr}$ system. The effect of alkalinization on the creatine phosphokinase equilibrium is to increase $[A D P]_{\text {free }}$ and $[A M P]_{\text {ree }}$ (Connett, 1987), both of which also stimulate phosphofructokinase (Goldhammer and Paradies, 1979; Ueda, 1979). Thus, in nerve tissue, as in other cell systems (Wu and Davis, 1981; Fidelman et al., 1982; Connett, 1987), pH may be an important regulator of cellular energy synthesis. By modulating the glycolytic flux, $\mathrm{H}^{+}$not only controls provision of ATP for direct use by metabolic functions, but also affects the supply of pyruvate for the mitochondrial respiratory chain. This possibility is especially appealing in view of the recent finding (Chesler and Kraig, 1989) that electrical stimulation of brain and increase in external $\left[\mathrm{K}^{+}\right]$are accompanied by a considerable alkalinization of glial cells. Because it is generally accepted that potassium released from neurons is taken up by glial cells, such independent enhancement of cellular ATP synthesis may greatly facilitate the operation of the $\mathrm{Na} / \mathrm{K}$ pump. In this context and in view of our results, we find it difficult to explain the data of Yarowsky et al. (1986), who reported that the large enhancement of 2-deoxyglucose uptake in monensin-treated cultured astrocytes was completely eliminated by ouabain. Their observations would suggest either that there is no monensin-induced change in $\mathrm{pH}_{i}$ in astrocytes or that the high glycolytic rate seen in these cells is not regulated by protons.

\section{Control of cellular ATP synthesis by Na/K pump activity}

Our study also demonstrates that the proportion of energy provided by glycolysis for support of the $\mathrm{Na} / \mathrm{K}$ pump, the key ATPconsuming reaction in the nerve tissue (Erecinska and Silver, 1989), can be increased substantially when activity of the pathway is independently stimulated. This is illustrated by a comparison of the data obtained in synaptosomes treated with mo- 
nensin (present results) and veratridine (Erecińska and Dagani, 1990). Both manipulations increase the $\left[\mathrm{Na}^{+}\right]_{i}$ and hence the pump activity, but only the former causes a decrease in $\left[\mathrm{H}^{+}\right]_{i}$. Using the data in Table 1 and assuming stoichiometric factors of 6 and 1, respectively, for the formation of ATP from the rates of oxygen uptake and lactate generation, it can be calculated that during the first $5 \mathrm{~min}$ incubation with monensin the latter process supplies $5.73 \mathrm{nmol} \Lambda \mathrm{TP} / \mathrm{min} / \mathrm{mg}$ protein, that is, $26 \%$ of the total energy consumed by the pump. This is considerably larger than the figure of $4 \%$ obtained in veratridine-stimulated preparations (Erecińska and Dagani, 1990). Similar calculations performed for C6 cells (Table 4) show that in this cell line, which is capable of high rates of aerobic lactate synthesis, glycolysis furnishes $31 \%$ of ATP for the ouabain-sensitive ion movements in the absence of monensin and $50 \%$ in its presence. The postulate that glycolysis can serve as an effective source of energy for the $\mathrm{Na} / \mathrm{K}$ ATPase when it is able to provide a high-enough [ATP] to ensure proper operation of the pump is supported by a number of observations in the literature. In vascular smooth muscle, which derives $30-50 \%$ of its total ATP synthesis from glycolysis, the $\mathrm{Na} / \mathrm{K}$ ATPase is maintained almost exclusively by this pathway (Paul et al., 1979; Lynch and Paul, 1983; Paul, 1983; Lynch and Balaban, 1987; Mertens et al., 1990). In contrast, in the poorly glycolyzing renal tubules (Balaban et al., 1980) and mammalian brain (Balázs, 1970; Hawkins et al., 1974), oxidative phosphorylation is the main source of energy. In other types of smooth muscle such as anococcygeus (Davidheiser et al., 1985) or taenia caecum (Takai and Tomita, 1986), which are endowed with moderate levels of glycolytic activity, both energy-producing pathways fuel the pump. Taken together, all these results indicate that differences in the patterns of energy support for the $\mathrm{Na} / \mathrm{K}$ pump are determined not only by a particular combination in the levels of the regulatory factors of oxidative phosphorylation and glycolysis (e.g., [ATP], [ADP], [AMP], $\left.[\mathrm{CrP}],\left[\mathrm{P}_{\mathrm{i}}\right]\right)$ but also by the genetic makeup of the cell.

\section{Effects of monensin on internal ion activities}

The second objective of the present work was to evaluate alterations in internal ions that occur upon exposure of cultured neurons, C6 cells, and synaptosomes to monensin and to correlate them with the metabolic responses. Although the primary effect of monensin is on $\left[\mathrm{Na}^{+}\right]_{i}$ and $\left[\mathrm{H}^{+}\right]_{i}$, secondary changes in concentrations of other ions are likely to take place because their gradients and movements are often interrelated. For this reason, we have measured not only $\left[\mathrm{Na}^{+}\right]_{i}$ and $\left[\mathrm{H}^{+}\right]_{i}$ but also $\left[\mathrm{Ca}^{2+}\right]_{i}$, membrane potential, and $\left[\mathrm{K}^{+}\right]_{i}$ and provide, to the best of our knowledge, the first systematic evaluation of their behavior. One of the interesting features of the present study is the unexpected, and distinct, response of synaptosomes to monensin.

Monensin at $10 \mu \mathrm{M}$ causes about a doubling of $\left[\mathrm{Na}^{+}\right]_{i}$ in both C6 cells and cultured neurons. However, owing to their different resting levels, the final sodium concentrations attained are much lower in C6 cells (11-12 $\mathrm{mm}$ ) than in cultured neurons (45-50 $\mathrm{mM})$. It can be surmised that, in synaptosomes in which under nonstimulated conditions the $\left[\mathrm{Na}^{+}\right]_{i}$ is $27-29 \mathrm{mM}$ (Erecinska et al., 1986), addition of monensin causes a change of approximately the same magnitude as that in neurons. The increase in $\left[\mathrm{Na}^{+}\right]_{i}$ enhances the activity of the $\mathrm{Na}^{+} / \mathrm{K}^{+}$ATPase, as expected. The stimulation is greater in synaptosomes than in $\mathrm{C} 6$ cells because the $\mathrm{K}_{\mathrm{m}}$ of the enzyme for $\mathrm{Na}^{+}$is $15-25 \mathrm{~mm}$ (Glynn and Karlish, 1975; Kimelberg et al., 1978; Schuurmans and Bonting, 1981; Sejersted et al., 1988; but see Logan, 1980, for a much higher value of $80 \mathrm{~mm}$ ), and the activation of the pump is very steep with a Hill coefficient of between 2 and 3 (Haber et al., 1987). In C6 cells, the rate of ouabain-sensitive ${ }^{86} \mathrm{Rb}$ influx is doubled by addition of $10 \mu \mathrm{M}$ monensin, whereas the same rise in the uptake of radioactive tracer in synaptosomes occurs at a considerably lower concentration $(4 \mu \mathrm{M})$. The total ouabainsensitive expenditure of energy by $\mathrm{C} 6$ cells in the presence of monensin (Table 4$)$ is $[(6.86-5.54) \times 6+(20.84-13.46) \times$ 1] $=15.30 \mathrm{nmol} \mathrm{ATP} / \mathrm{min} / \mathrm{mg}$ dry weight, approximately twice that found in the absence of the antibiotic $(8.62 \mathrm{nmol} / \mathrm{min} / \mathrm{mg}$ dry wt). The same calculation for synaptosomes (Table 1) shows that $10 \mu \mathrm{M}$ monensin augments the ouabain-sensitive ATP production fivefold. It is interesting that the $\mathrm{Rb} / \mathrm{ATP}$ calculated from the data on C6 cells is about 2 , consistent with the wellestablished stoichiometry of the $\mathrm{Na} / \mathrm{K}$ pump (Glynn and Karlish, 1975; Schuurmans and Bonting, 1981).

In all three systems studied, monensin causes internal alkalinization. However, whereas in cultured neurons and C6 cells $\mathrm{pH}$ rises by about $0.4-0.5 \mathrm{pH}$ unit (Figs. 5,6 ), it increases only by $0.1-0.15 \mathrm{pH}$ unit in synaptosomes (Fig. 4). A difference between the cells and the nerve endings is that the latter contain a vesicular (transmitter-containing) compartment with a very acid internal pH (Deutsch et al., 1981). Monensin, which easily penetrates insidc cclls, may insert itself in the membranes of these vesicles and mediate a release of internal protons in exchange for cytosolic $\mathrm{Na}^{+}$or $\mathrm{K}^{+}$. Cytoplasmic acidification will thus ensue, which will be superimposed on alkalinization caused by the operation of the antibiotic located in the plasma membrane. Hence, the final internal $\mathrm{pH}$ in synaptosomes is a function of these two opposing reactions and is determined by the relative strength of each. It is interesting that, in chromaffin cells of the adrenal medulla, treatment with monensin results in internal acidification and not alkalinization (Kuijpers et al., 1989), which suggests that the antibiotic-mediated release of protons from the large acidic, amine-containing compartment into the cytosol is greater than their loss through the plasma membrane.

\section{Monensin-induced depolarization of the synaptosomal plasma membrane}

The key feature that distinguishes the action of monensin in cells from that in synaptosomes is the behavior of the plasma membrane potential. In the former, a transient small depolarization is followed by repolarization and later in some instances by a small hyperpolarization. The simplest explanation is that the antibiotic, which catalyzes an electroneutral exchange of $\mathrm{Na}^{+}$ or $\mathrm{K}^{+}$for $\mathrm{H}^{+}$and shows only a 10:1 selectivity for $\mathrm{Na}^{+}$over $\mathrm{K}^{+}$ (Pressman, 1976), causes a release of $\mathrm{K}^{\prime}$ from cells via a $\mathrm{K}^{+}$ $\mathrm{H}^{+}$exchange mechanism. Because in both cell types the membrane potential is the $\mathrm{K}^{+}$diffusion potential, depolarization will follow. However, when the monensin-induced increase in $\left[\mathrm{Na}^{+}\right]$ stimulates the activity of the pump, the enhanced rate of $\mathrm{K}^{+}$ uptake restores, in due course, its original internal concentration. In contrast, in nerve endings the antibiotic causes massive depolarization and potassium loss, which are difficult to reconcile with the considerations above and the observation that synaptosomes contain a powerful $\mathrm{Na} / \mathrm{K}$ pump (Erccińska and Dagani, 1990). The question that arises is what is responsible for this unorthodox behavior.

The first possibility to be considered is that the $\mathrm{K}^{+} / \mathrm{H}^{+}$exchange contributes substantially to $\mathrm{K}^{+}$loss because synaptosomes have an unusually high affinity for monensin and bind and/or incorporate large amounts of the antibiotic. The latter 
suggestion is based on the reports (Mollenhauer et al., 1990) that solubility, penetration, and expression of monensin action depend on properties of the membrane (such as its fluidity, thickness, curvature, charge) and orientation of the phospholipid head groups as well as cholesterol and protein content. However, if this was the only explanation for the observed leakage of $\mathrm{K}^{+}$, one would expect that at very low [monensin] there would be no depolarization because the high selectivity for $\mathrm{Na}^{+}$ versus $\mathrm{K}^{+}$is a property of the antibiotic and not of the membrane. This prediction is not substantiated by the experimental results, which show that a decrease in membrane potential occurs at the lowest concentration of monensin used. Moreover, if the $\mathrm{K}^{+} / \mathrm{H}^{+}$exchange were the sole mechanism for $\mathrm{K}^{+}$loss and depolarization, it should not be affected by $\mathrm{Na}^{+}$withdrawal. This is again contrary to the experimental findings. Thus, there must be other reasons for the observed effects. The most likely of these is that monensin itself, or a consequence of its action, opens a rather nonselective cation channel that allows diffusion of $\mathrm{Na}^{+}$and $\mathrm{Ca}^{+}$inward and $\mathrm{K}^{+}$outward, that is, down their concentration gradients with consequent decrease in plasma membrane voltage and reduction in $\left[\mathrm{K}^{+}\right]_{i} /\left[\mathrm{K}^{+}\right]_{e}$.

There are at least three types of cation channel that have been described in the literature whose activation could be responsible for membrane depolarization: $\mathrm{Ca}^{2+}$-activated nonspecific cation channels (Partridge and Swandulla, 1988), stretch-activated channels (Kullberg, 1987; Sachs, 1987), and Na-opened channels (Lemos and Nordmann, 1986). Calcium-activated, nonspecific cation channels have been found in several types of cells, including neurons (Hofmeier and Lux, 1981; Byerly and Moody, 1984; Lewis, 1984; Swandulla and Lux, 1985). Although the $\left[\mathrm{Ca}^{2+}\right]$ that activates this channel differs substantially from one system to another (Partridge and Swandulla, 1988), a rise in the intracellular level of the cation is mandatory. However, monensin-induced depolarization of synaptosomes and $\mathrm{K}^{+}$ loss is independent of the presence or absence of external calcium. Thus, unless the putative synaptosomal channels are activated by $\left[\mathrm{Ca}^{2+}\right]$ as low as $50 \mathrm{~nm}$ (such as is measured in the calcium-free medium), a rather unprecedented event (Partridge and Swandulla, 1988), the simplest interpretation is that the rise in $\left[\mathrm{Ca}^{2+}\right]_{i}$ that follows monensin addition is not a cause but rather a consequence of the antibiotic action.

Stretch-activated ion channels, initially described in embryonic skeletal muscle (Guharay and Sachs, 1984), have been found recently in cultured astrocytes (Kimelberg et al., 1990). They can be opened by an increase in osmotic pressure, such as occurs during cell swelling, and thus would be expected to be sensitive to the presence of chloride and inhibitors of anion transport. However, in synaptosomes neither replacement of chloride with gluconate nor addition of SITS had any effect on $\mathrm{K}^{+}$leakage. Thus, it is unlikely that stretch-activated channels are responsible for monensin-induced depolarization of the nerve endings, though it is always possible that the putative channels are insensitive to such treatments.

The third type of channel whose activation could cause a decrease in membrane voltage is an $\mathrm{Na}^{+}$-activated pore. It has been described in peptidergic nerve terminals from a crustacean neurosecretory system (Stuenkel et al., 1990) and rat pituitary neural lobe (Lemos and Nordmann, 1986) and shown to have nearly equal permeability to $\mathrm{Na}^{+}$and $\mathrm{K}^{+}$but not to divalent cations. Opening of such channels would cause an influx of $\mathrm{Na}^{+}$ into and an efflux of $\mathrm{K}^{+}$out of synaptosomes, with consequent collapse of their gradients and membrane depolarization. Al- though these predictions are matched by the experimental findings summarized in this article, the very existence of such channels in mammalian synaptosomes remains a matter of speculation until their identification is carried out at the level of singlechannel recordings.

In addition to changes in $\left[\mathrm{Na}^{+}\right]_{i}$ and $\left[\mathrm{H}^{+}\right]_{i}$, monensin induces a rise in the concentration of internal calcium that is small in neurons and $\mathrm{C} 6$ cells but large in synaptosomes. This difference in magnitude is due to dissimilarities in mechanisms responsible for changes in calcium concentrations. In cells, where depolarization is too small to open the voltage-operated channels, alterations in internal sodium and protons determine the final levels of $\mathrm{Ca}^{2+}$ (Silbergeld, 1977; Crompton et al., 1978; Nicholls, 1978; Harris and Heffron, 1982; Busa and Nuccitelli, 1984; Moody, 1984; DiPolo and Beaugé, 1988). However, the smallness of the gain in $\left[\mathrm{Ca}^{2+}\right]_{i}$ suggests either that these mechanisms do not contribute significantly to a rise in the concentration of the cation consequent upon $\mathrm{Na}^{+}$entry and decrease in $\left[\mathrm{H}^{+}\right]_{i}$, or that the calcium buffering/extrusion processes are powerful enough to deal with the load. In contrast, in synaptosomes calcium flows in from outside via the voltage-controlled channels opened by large depolarization of the plasma membrane. It is worth mentioning that both depolarization and increase in internal calcium can cause release of transmitter amino acids ( $\mathrm{Ta}$ ble 3). The insensitivity of this release to calcium withdrawal observed by us and others (see Sitges, 1989, for an increase in monensin-triggered GABA secretion in the absence of calcium) indicates that the predominant effect is the nonexocytotic efflux contingent upon decrease in the driving force (i.e., combination of the membrane potential and the Na gradient) for amino acid accumulation.

\section{Physiological implications of the findings with monensin}

Our final comment concerns the use of monensin as a tool for understanding relations between alterations in intracellular ions and metabolic responses, as well as among intracellular ions themselves. This antibiotic mimics the action of several external signals, including growth factors, phorbol esters, hormones, neurotransmitters, and chemotactic peptides (for review, see Moolenaar, 1986; Rozengurt, 1986; Frelin et al., 1988; Grinstein et al., 1989), because all of these stimulate the plasma-membrane $\mathrm{Na}^{+} / \mathrm{H}^{+}$exchanger. Because such a protein has been shown to be quite active in synaptosomes (Jean et al., 1985) and glial cells (Benos and Sapirstein, 1983; Jean et al., 1986), our results provide insight into the possible consequences of the action of these stimulants in brain in vivo.

\section{References}

Balaban RS, Mandel LJ, Soltoff SP, Storey JM (1980) Coupling of active ion transport and aerobic respiratory rate in isolated renal tubules. Proc Natl Acad Sci USA 77:447-451.

Balázs R (1970) Carbohydrate metabolism. In: Handbook of neurochemistry (Lajtha A, ed), pp 1-36. New York: Academic.

Benos DJ, Sapirstein VS (1983) Characteristics of an amiloride-sensitive sodium entry pathway in cultured rodent glial and neuroblastoma cells. J Cell Physiol 116:213-220.

Blaustein MP, Goldring JM (1975) Membrane potentials in pinchedoff presynaptic nerve terminals monitored with a fluorescent probe: evidence that synaptosomes have potassium diffusion potentials. $J$ Physiol (Lond) 247:589-615.

Booth R, Clark JB (1978) A rapid method for the preparation of relatively pure, metabolically competent synaptosomes from rat brain. Biochem J 176:365-370.

Busa WB, Nuccitelli R (1984) Metabolic regulation via intracellular pH. Am J Physiol 246:R409-R438. 
Byerly L, Moody WJ (1984) Intracellular calcium ions and calcium currents in perfused neurones of the snail Lymnaea stagnalis. J Physiol (Lond) 352:637-652.

Chesler M, Kraig MP (1989) Intracellular pH transients of mammalian astrocytes. J Neurosci 9:2011-2019.

Connett RJ (1987) Glycolytic regulation during an aerobic rest-towork transition in dog gracilis muscle. J Appl Physiol 63:2366-2374.

Crompton M, Moser R, Ludi H, Carafoli E (1978) The interrelations between transport of sodium and calcium in mitochondria of various mammalian tissues. Eur J Biochem 82:25-31.

Davidheiser S, Joseph J, Davies RE (1985) Separation of aerobic glycolysis from oxidative metabolism and contractility in rat anococcygeus muscle. Am J Physiol 247:C335-C341.

Deutsch CJ, Rafalowska U, Drown C, Silver IA (1981) Synaptosomes from rat brain: morphology, compartmentation and transmembrane $\mathrm{pH}$ and electrical potentials. J Neurochem 36:2063-2072.

Diamond I, Fishman RA (1973) High-affinity transport and phosphorylation of 2-deoxyglucose in synaptosomes. J Neurochem 20: $1533-1542$.

DiPolo R, Beaugé L (1988) $\mathrm{Ca}^{2+}$ transport in nerve fibers. Biochim Biophys Acta 947:549-569.

Erecińska $M$ (1989) Stimulation of the $\mathrm{Na} / \mathrm{K}$ pump activity during electrogenic uptake of acidic amino acid transmitters by rat brain synaptosomes. J Neurochem 52:135-139.

Erecińska M, Dagani F (1990) Relationships between the neuronal sodium/potassium pump and energy metabolism: effects of $\mathrm{K}^{+}, \mathrm{Na}^{+}$ and adenosine triphosphate in isolated brain synaptosomes. J Gen Physiol 95:591-616.

Erecińska M, Silver IA (1986) The role of glia cells in regulation of neurotransmitter amino acids in the external environment. I. Transmembrane electrical and ion gradients and energy parameters in cultured glial-derived cell lines. Brain Res 369:193-202.

Erecińska M, Silver IA (1987) Energy relationships between ATP synthesis and $\mathrm{K}^{+}$gradients in cultured glial-derived cell line. Acta Biochim Pol 34:195-203.

Erccińska M, Silver IA (1989) ATP and brain function. J Cereb Blood Flow Metab 9:2-19.

Erecińska M, Wantorsky D, Wilson DF (1983) Aspartate transport in synaptosomes from rat brain. J Biol Chem 258:9069-9077.

Erecińska M, Troger MB, Alston TA (1986) Neurotransmitter amino acids in the CNS: properties of diaminobutyric acid transport. J Neurochem 46:1452-1457.

Fidelman ML, Seeholzer SH, Walsh KB, Moore RD (1982) Intracellular $\mathbf{p H}$ mediates action of insulin on glycolysis in frog skeletal muscle. Am J Physiol 242:C87-C93.

Frelin C, Vigne P, Ladoux A, Lazdunski M (1988) The regulation of the intracellular $\mathrm{pH}$ in cells from vertebrates. Eur J Biochem 174:314.

Glynn IA, Karlish S (1975) The sodium pump. Annu Rev Physiol 37: $13-55$.

Goldhammer AR, Paradies HH (1979) Phosphofructokinase: structure and function. Curr Top Cell Reg 15:109-141.

Grinstein S, Goetz JD (1985) Control of free cytoplasmic calcium by intracellular pH in rat lymphocytes. Biochim Biophys Acta 819:267270.

Grinstein S, Rotin D, Mason MJ (1989) $\mathrm{Na}^{+} / \mathrm{H}^{+}$exchange and growth factor-induced cytosolic $\mathrm{pH}$ changes. Role in cellular proliferation. Biochim Biophys Acta 988:73-97.

Guharay F, Sachs F (1984) Stretch-activated single ion channel-currents in tissues-cultured embryonic skeletal muscle. J Physiol (Lond) 352:685-701.

Haber RS, Pressley TA, Loeb JN, Ismail BF (1987) Ionic dependence of active $\mathrm{Na}-\mathrm{K}$ transport: 'clamping' of cellular $\mathrm{Na}^{+}$with monensin. Am J Physiol 253:F26-F33.

Hansen AJ (1985) Effect of anoxia on ion distribution in the brain. Physiol Rev 65:101-148.

Harris EJ, Heffron J (1982) The stimulation of the release of $\mathrm{Ca}^{2+}$ from mitochondria by sodium ions and its inhibition. Arch Biochem Biophys 218:531-539.

Hawkins RA, Miller AL, Cremer JE, Veech RL (1974) Measurement of the rate of glucose utilization by rat brain in vivo. J Neurochem 23:917-923.

Hofmeier G, Lux HD (1981) The time course of intracellular free calcium and related electrical effects after injection of $\mathrm{CaCl}_{2}$ into neurons of the snail Helix pomatia. Pfluegers Arch 391:242-251.
Jarret HW, Cooksy KD, Ellis B, Anderson LM (1986) The separation of $o$-phthalaldehyde derivatives of amino acids by reversal phase chromatography on octylsilica column. Anal Biochem 153:189-198.

Jean T, Frelin C, Vigne P, Barbry P, Lazdunski M (1985) Biochemical properties of the $\mathrm{Na}^{+} / \mathrm{H}^{+}$exchange system in rat brain synaptosomes. J Biol Chem 260:9678-9684.

Jean T, Frelin C, Vigne P, Lazdunski M (1986) The $\mathrm{Na}^{+} / \mathrm{H}^{+}$exchange system in glial cell lines. Properties and activation by an hyperosmotic shock. Eur J Biochem 160:211-219.

Kimelberg H, Anderson E, Kettenmann, H (1990) Swelling-induced changes in electrophysiological properties of cultured astrocytes and oligodendrocytes. II. Whole-cell currents. Brain Res 529:262-268.

Kimelberg HK, Biddlecome S, Narumi S, Bourke RS (1978) ATPase and carbonic anhydrase activities of bulk isolated neurons, glia and synaptosome fractions from rat brain. Brain Res 141:305-323.

Kuijpers G, Rosario LM, Ornberg RL (1989) Role of intracellular pH in secretion from adrenal medulla chromaffin cells. J Biol Chem 264 $698-705$

Kullberg R (1987) Stretch-activated ion channels in bacterial and animal cell membranes. Trends Neurosci 10:38-39.

Lemos JR, Nordmann JJ (1986) Ionic channels and hormone release from peptidergic nerve terminals. J Exp Biol 124:53-72.

Lewis DL (1984) Spike aftercurrents in R15 neurons of Aplysia: their relationship to slow inward current and calcium influx. $J$ Neurophysiol 51:387-403.

Logan JG (1980) The extrusion of sodium ions from presynaptic nerve endings of rat cerebral cortex. J Neurochem 35:349-353.

Lynch RM, Balaban RS (1987) Energy metabolism in renal cell lines, AG and MDCK: regulation by $\mathrm{Na}^{+}-\mathrm{K}^{+}$-ATPase. Am J Physiol 252 $\mathrm{C} 225-\mathrm{C} 231$

Lynch RM, Paul RJ (1983) Compartmentation of glycolytic and glycogenolytic metabolism in vascular smooth muscle. Science 222:1344 1346.

Mertens S, Noll T, Spahr R, Krutzfeldt A, Piper HM (1990) Energetic response of coronary endothelial cells to hypoxia. Am J Physiol 258 : H689-H694.

Meyer RA, Sweeney HL, Kushmerick MJ (1984) A simple analysis of the 'phosphocreatine shuttle.' Am J Physiol 246:C365-C377.

Mollenhauer HH, Morré DJ, Rowe LD (1990) Alteration of intracellular traffic by monensin; mechanism, specificity and relationship to toxicity. Biochim Biophys Acta 1031:225-246.

Moody W (1984) Effects of intracellular $\mathrm{H}^{+}$on the electrical properties of excitable cells. Annu Rev Neurosci 7:257-278.

Moolenaar WH (1986) Effects of growth factors on intracellular $\mathrm{pH}$ regulation. Annu Rev Physiol 48:363-376.

Nachschen DA, Drapeau P (1988) The regulation of cytosolic pH in isolated presynaptic nerve terminals from brain. J Gen Physiol 91: 289-303.

Nicholls D (1978) Calcium transport and proton electrochemical potential gradicnt in mitochondria from guinca-pig cerebral cortex and rat heart. Biochem J 170:511-522.

Partridge LD, Swandulla D (1988) Calcium-activated non-specific cation channels. Trends Neurosci 11:69-72.

Paul RJ (1983) Functional compartmentalization of oxidative and glycolytic metabolism in vascular smooth muscle. Am J Physiol 244: C399-C409.

Paul RJ, Bauer M, Pease W (1979) Vascular smooth muscle: aerobic glycolysis linked to sodium and potassium transport processes. Science 206:1414-1416.

Pressman BC (1976) Biological applications of ionophores. Annu Rev Biochem 45:501-530.

Pressman BC, Fahim M (1982) Pharmacology and toxicology of the monovalent carboxylic ionophores. Annu Rev Pharmacol Toxicol 22:465-490.

Rottenberg H (1979) The measurement of membrane potential and delta $\mathrm{pH}$ in cells, organelles and vesicles. Methods Enzymol 55:547569.

Rozengurt E (1986) Early signals in the mitogenic response. Science 234:161-166.

Sachs F (1987) Baroreceptor mechanisms at the cellular level. Fed Proc 46:12-16.

Schuurmans SF, Bonting SL (1981) Transport adenosine triphosphatases: properties and functions. Physiol Rev 61:1-77.

Scott IA, Nicholls DG (1980) Energy transduction in intact synaptosomes. Biochem J 186:21-33. 
Sejersted OM, Wassestrom JA, Fozzard HA (1988) Na, K pump stimulation by intracellular $\mathrm{Na}$ in isolated intact sheep cardiac Purkinje fibrcs. J Gen Physiol 91:445-466.

Siffert W, Akkerman J (1989) Cytosolic alkalinization alone is not sufficient for $\mathrm{Ca}^{2+}$ mobilization, phosphatidic acid formation, and protein phosphorylation in human platelets. Biochem Biophys Res Commun 161:1007-1012.

Silbergeld EK (1977) $\mathrm{Na}^{+}$regulates release of $\mathrm{Ca}^{2+}$ sequestered in synaptic mitochondria. Biochem Biophys Res Commun 77:464-469.

Silver IA, Erecińska M (1990) Intra- and extracellular changes of $\left[\mathrm{Ca}^{2+}\right]$ in hypoxia and ischemia in rat brain in vivo. J Gen Physiol 95:837866.

Sitges M (1989) Characterization of the effect of monensin on $\gamma$-amino- $n$-butyric acid release from isolated nerve terminals. J Neurochem $53: 442-447$

Stuenkel EL, Ruben P, Cooke IM, Lemos JR (1990) Sodium-activated cation channels in peptidergic nerve terminals. Brain Res 517:35-43.

Swandulla D, Lux HD (1985) Activation of a non-specific cation conductance by intracellular $\mathrm{Ca}^{2+}$ elevation in bursting pacemaker neurons of Helix pomatia. J Neurophysiol 54:1430-1443.

Takai A, Tomita T (1986) Glycolysis and oxidative phosphorylation during activation of the sodium pump in the taenia from guinea-pig caecum. J Physiol (Lond) 381:65-75.

Trivedi B, Danforth WH (1966) Effect of pII on the kinetics of frog muscle phosphofructokinase. J Biol Chem 241:4110-4112.

Ueda K (1979) Phosphofructokinase. Adv Enzymol 48:194-244.

White EJ, Juchniewicz HJ, Clark JB (1989) Effect of lactic acidosis on the function of cerebral cortical synaptosomes. J Neurochem 52: 154-161.

Wu TFL, Davis EJ (1981) Regulation of glycolytic flux in an energetically controlled cell-free system: the effects of adenine nucleotide ratios, inorganic phosphate, $\mathrm{pH}$ and citrate. Arch Biochem Biophys 209:85-99.

Yarowsky P, Boyne AF, Wierwille R, Brookes N (1986) Effect of monensin on deoxyglucose uptake in cultured astrocytes: energy metabolism is coupled to sodium entry. J Neurosci 6:859-866. 